\title{
Electron Capture Dissociation of Peptides Metalated with Alkaline-Earth Metal Ions
}

\author{
Y. M. Eva Fung, Haichuan Liu, and T.-W. Dominic Chan \\ Department of Chemistry, The Chinese University of Hong Kong, Hong Kong SAR
}

\begin{abstract}
The possible use of divalent alkaline-earth metal ions, including $\mathrm{Mg}^{2+}, \mathrm{Ca}^{2+}, \mathrm{Sr}^{2+}$, and $\mathrm{Ba}^{2+}$, as charge carrier for electron capture dissociation of peptides was investigated. Model peptides of RGGGVGGGR and NGGGWGGGN were used to simplify the interpretation of spectral information. It was demonstrated that useful electron capture dissociation (ECD) tandem mass spectra of these metalated peptides could be generated. Interestingly, peptides metalated with different alkaline-earth metal ions generated very similar ECD tandem mass spectra. Metalated $c$-ions and $z$-ions were the predominant fragment ions. Only $\mathrm{Mg}^{2+}$-metalated peptides gave somewhat different results. Some nonmetalated $c$-ions were observed from ECD of [RGGGVGGGR $+\mathrm{Mg}^{2+}$ but not from [NGGGWGGGN $\left.+\mathrm{Mg}\right]^{2+}$. Together with some ab initio calculations, it was established that the bound metal ions might activate the acidity of the amide hydrogen. With the presence of high proton affinity moiety, such as N-terminal amino group and/or side chain of the arginine residues, the metalated peptide ions could exist predominantly in their zwitterion forms, in which one or two backbone amide group(s) was deprotonated and the high proton affinity functional group(s) was protonated. It was believed that electron capture leads primarily to the reduction of the mobile proton rather than the metal ions. With this zwitterion model, the formation of nonmetalated c-fragments and the generation of similar ECD spectra for peptides metalated with various alkaline-earth metal ions could readily to be explained. Another interesting observation in the ECD mass spectra of metalated peptides is related to the enhanced formation of the minor ECD products, i.e., ( $c-$ $1)^{+}$and $(z+1)^{+}$ions. Together with ab initio calculations using a truncated peptide model, various possible reaction mechanisms for the formation of these minor ECD products were evaluated. It was concluded that hydrogen transfer between the initiated formed $\mathrm{c}$ and $\mathrm{z}$ species plays an important role in the formation $(c-1)^{+\bullet}$ and $(z+1)^{+}$ions. Although peptides metalated with these metal ions do not have better ECD efficiency compared to the multiply-protonated peptides, it provides practical accessibility of ECD methods to analyze small peptides with no basic amino acid residues. (J Am Soc Mass Spectrom 2006, 17, 757-771) @ 2006 American Society for Mass Spectrometry
\end{abstract}

$\mathrm{E}$ lectron capture dissociation (ECD) is an important technique for de novo sequencing of polypeptides using mass spectrometry [1]. The multiply-protonated polypeptide species become radicals upon electron capture. For peptides/proteins, radical initiated reactions have different cleavage preferences (i.e., $c$ - and $z$-type fragments) compared to those initiated by proton in even-electron systems (i.e., $b$ - and $y$-type fragments) $[2,3]$. ECD can therefore provide complimentary information through the formation of different sequence-specific ion series. Another important feature of ECD of peptides/proteins is the retention of post-translational modified groups when the peptide backbone is cleaved [4,5]. A combination of ECD and other dissociation techniques allows simultaneous lo-

Published online April 17, 2006

Address reprint requests to Dr. T.-W. D. Chan, Department of Chemistry, The Chinese University of Hong Kong, Shatin, N.T., Hong Kong SAR, China. E-mail: twdchan@cuhk.edu.hk calization and characterization of post-translational modifications [6-9].

In attempts to improve the performance of ECD method, many studies have been conducted to examine the effect of common experimental parameters on the abundance and types of ECD fragments [10, 11]. Although the electron capture cross-section by a positive ion has previously been measured to be highest when subthermal electrons are used [12], useful ECD spectra could still be generated when the peptide/protein ions trapped in typical ICR cell were irradiated by electrons with a broad range of energies ( $\sim 0$ to $50 \mathrm{eV}$ ) [10, 11]. Apart from the predominant $\mathrm{N}-\mathrm{C}_{\alpha}$ cleavage, electron capture dissociation with high-energy electrons $(>3 \mathrm{eV})$ was believed to induce secondary fragmentation leading to the loss of amino acid side chains [13-16] from both the reduced precursor ions and from labile $z$ fragments. This feature allows direct mass spectrometric differentiation of leucine and isoleucine during sequence determination of polypeptides [15]. Through presumably the cooling of the incoming electrons and 
Table 1. A summary of the physical and chemical information ${ }^{\text {a }}$ related to alkaline-earth metal ions

\begin{tabular}{|c|c|c|c|c|c|c|c|}
\hline \multirow[b]{2}{*}{ Element } & \multirow[b]{2}{*}{ Symbol } & \multirow[b]{2}{*}{$\begin{array}{c}\text { 1st IP } \\
(\mathrm{kJ} / \mathrm{mol})\end{array}$} & \multirow[b]{2}{*}{$\begin{array}{c}\text { 2nd IP } \\
(\mathrm{kJ} / \mathrm{mol})\end{array}$} & \multirow{2}{*}{$\begin{array}{c}\text { Common } \\
\text { coordination } \\
\text { numbers }^{a}\end{array}$} & \multicolumn{3}{|c|}{ Ionic Radius ${ }^{\mathrm{b}}(\AA ̊)$} \\
\hline & & & & & 4-coordinated & 6 -coordinated & 8-coordinated \\
\hline Hydrogen & $\mathrm{H}$ & 1312.0 & - & - & - & - & - \\
\hline Magnesium & $\mathrm{Mg}$ & 737.7 & 1450.7 & $4,6,8$ & 0.71 & 0.86 & 1.03 \\
\hline Calcium & $\mathrm{Ca}$ & 589.8 & 1145.4 & 6,8 & - & 1.14 & 1.26 \\
\hline Strontium & $\mathrm{Sr}$ & 549.5 & 1064.2 & 6,8 & - & 1.32 & 1.40 \\
\hline Barium & $\mathrm{Ba}$ & 502.9 & 965.2 & 6,8 & - & 1.49 & 1.56 \\
\hline
\end{tabular}

a Data obtained from reference [28].

${ }^{\mathrm{b}}$ For doubly-charged species.

the ECD fragments, ECD experiments utilizing simultaneous pulse-gas cooling and electron irradiation were found to produce better quality ECD spectra [10]. High quality ECD spectra could also be generated by increasing the cyclotron radius of the trapped ions using sustained off-resonance irradiation (SORI) method [17]. The enhanced performance was attributed to a better overlapping between the incoming electron beam and the ion cloud within the trapped ion cell [17]. This is consistent with the results obtained by replacing the conventional heated filament with indirectly heated dispenser cathode [18] for production of low-energy electrons. Apart from a better control of the electron energy, the larger electron beam cross-sectional area could shorten the typical electron irradiation time from seconds to milliseconds [18]. This allows direct coupling of LC separation with real-time MS/MS experiments using ECD as ion activation method [19-21]. The role of thermal background on the ECD of peptides has also been evaluated. While decreasing the temperature of the trapped-ion cell to $86 \mathrm{~K}$ decreases the number of sequence specific fragment ions [22], increasing cell temperature to $423 \mathrm{~K}$ was found to generate more $z$ ions but not $c$ ions [23]. For analysis of larger proteins, additional ion activation through collisions or infrared irradiation was found to be essential in breaking the noncovalent interactions within the ECD induced fragments [24, 25].

Use of metal ion as charge carrier for ECD of peptides potentially provides more complementary sequence information compared to protonated peptides. Based on the ion-electron recombination energy, as deduced from the ionization potential, the use of metal ions as charge carriers for ECD might provide a tunable parameter for internal energy deposition during the electron capture event. In addition, the binding properties of metal ions are different from that of protons. This might lead to the formation of different sequence specific fragment ions. Previously, Williams and coworkers demonstrated the use of alkali metal ions $\left(\mathrm{Li}^{+}\right.$and $\left.\mathrm{Cs}^{+}\right)$ as charge carriers for ECD of peptides [23]. ECD of the metalated dications yields the lithiated and cesiated analogues of the same range of $c$ and $z$ ions as those produced by ECD of the corresponding protonated species. Zubarev and coworkers performed ECD on angiotensin II using $\mathrm{Zn}^{2+}$ as charge carriers [26]. The resulting spectrum showed much less fragment ions but yielded complementary sequence information compared with protonated species. Marshall and coworkers demonstrated that ECD of simultaneously protonated and cationized oligodeoxynucleotide dications yielded more product ions than that generated from ECD of doubly protonated species [27].

In this study, we investigated the possible use of alkaline-earth metal ions as charge carriers for peptides for ECD experiments. There are several attractive properties of alkaline-earth metal ions. They are divalent metal ions with substantial differences in their second ionization potentials and coordinating chemistries. Table 1 [28] summarizes the ionization potentials and the coordination properties of alkaline-earth metals. Interestingly, the ionization potential of hydrogen lies between the second ionization potentials of these metals. Two model peptides, RGGGVGGGR and NGGGWGGGN, were used in this study to simplify spectral interpretation.

\section{Experimental}

\section{Sample Preparation}

All materials were obtained commercially and were used without further purification. Magnesium bromide was obtained from Janssen (Titusville, NJ), calcium chloride was obtained from Merck (Darmstadt, Germany), strontium acetate was obtained from BDH (Dorsetshire, UK), barium bromide was obtained from Beijing HuaGongChang (Beijing, China) and model peptides were custom-synthesized by Peptron Inc., (Daejeon, South Korea). The samples were prepared at concentrations of $1 \times 10^{-5}-1 \times 10^{-4} \mathrm{M}$ in 1:1 water: methanol (Labscan Ltd., Bangkok, Thailand). The concentrations of the metal salts were $5 \mathrm{mM}$ in peptide solutions.

\section{Instrumentation}

All experiments were performed by using a 4.7 tesla FTMS system (APEX III, Bruker Instrument Inc., Boston, MA). This instrument was equipped with standard, commercially available external electrospray ion source (Analytica, Branford, CT) [29]. The 
ESI ion source was modified to adopt a homemade nanospray assembly [30]. Eight to ten $\mu \mathrm{L}$ of sample solution was loaded into a tapered capillary tip and was electrically grounded using a $15 \mu \mathrm{m}$ gold-plated tungsten wire [30]. Intact molecular ions were produced and were briefly accumulated in a hexapole ion guide for up to $4 \mathrm{~s}$ before transferring into the Infinity Cell [31]. Ion transmission from the external source into the trapped ion cell was achieved by using the standard electrostatic lens system. Sidekick ion accumulation method was used to facilitate the ion trapping process. In all experiments, static trapping potentials of $1.0 \mathrm{~V}$ were used. Initial calibration of the instrument was achieved by using a peptide mixture containing LGF, angiotensin II, and melittin. A standard electrically heated filament source was used to produce pulses of electron beam. The filament was made of rhenium ribbon and was fixed at a distance of $108 \mathrm{~mm}$ from the rear end of the Infinity cell. Details of the geometry of the filament source have previously been described [10]. Typical experimental conditions were 3.3 A filament heating current, $5.4 \mathrm{~V}$ average filament bias voltage, and $500-$ $1000 \mathrm{~ms}$ electron irradiation time. All ECD mass spectra were acquired in broadband mode using 128 k-byte dataset. One hundred scans were normally summed to improve the signal-to-noise ratio. The time-domain signals were zero-filled once before Fourier transformation.

\section{Calculations}

Standard ab initio calculations were performed by using Gaussian 03 molecular orbital package [32]. Geometries were optimized with density functional theory calculation using spin-unrestricted Becke's hybrid UB3LYP functional [33] and the 6-31 $++G(d, p)$ basis set. The optimized structures were characterized by harmonic frequency analysis as local minima (all frequencies real) and first-order saddle points (single imaginary frequency). The UB3LYP frequencies were corrected by 0.9806 and were used to calculate zeropoint vibrational corrections [34]. Single-point energies were calculated at UB3LYP and UMP2 levels using the 6-311 ++ G(3df,2p) basis set. Complete optimized geometries (Cartesian coordinates), uncorrected harmonic frequencies, and total energies for all species are available as supporting information, which can be found in the electronic version of this article. Spin contamination in calculations with unrestricted wave functions was negligible to moderate. The $\left\langle\mathrm{S}^{2}\right\rangle$ operator expectation values were $0.75-0.77$ for UB3LYP calculations of local minima and transition states, $0.76-$ 0.94 for UMP2 calculations of local minima, and 0.790.94 for UMP2 calculations of transition states. Spin projection (PMP2) reduced the $\left\langle\mathrm{S}^{2}\right\rangle$ values to $0.75-$ 0.76 and resulted in total energy corrections of $<9$ mhartree $\left(22 \mathrm{kJmol}^{-1}\right)$. The single-point energies from the UB3LYP and spin-projected MP2 calculations were averaged and used to calculate to give B3-PMP2 relative energies that were corrected for zero-point vibrational energies. Due, presumably, to the cancellation of errors inherent to the estimation of correlation energies in PMP2 and UB3LYP methods, the empirical average of the relative energies obtained from these methods with adequately large basis sets was shown to have good fit with experimental data or results from high-level calculations [35].

\section{Results}

\section{ECD spectra of RGGGVGGGR Metalated with Alkaline-Earth Metal Ions}

Figure 1a-d show typical ECD mass spectra of RGGGVGGGR metalated with $\mathrm{Mg}^{2+}, \mathrm{Ca}^{2+}, \mathrm{Sr}^{2+}$, and $\mathrm{Ba}^{2+}$, respectively. The mass assignments of the corresponding Mg-metalated species are given in Table 2. The ECD spectra were internally calibrated using $[\mathrm{M}+$ $\mathrm{Cat}]^{2+},[\mathrm{M}+\mathrm{Cat}-\mathrm{H}]^{+}$and $[\mathrm{M}+\mathrm{Cat}-\mathrm{H}-\mathrm{HN}=$ $\left.\mathrm{C}\left(\mathrm{NH}_{2}\right)_{2}\right]^{+}$. Since there are several interesting features associated with the formation of unexpected fragment species, the commonly used nomenclature [13] cannot clearly describe the observed fragment species. A more explicit notation for labeling the fragment ions was adopted for clarity purposes. $\bar{c}-$ and $\bar{z}-$ fragments denote the corresponding $\mathrm{N}$ - and C-terminal fragments originated from the homolytic cleavage of the $\mathrm{N}-\mathrm{C}_{\alpha}$ linkage, respectively. In this notation, a radical is allocated on each fragment. Any surplus of proton/hydrogen atom and metal atom is indicated in the label, i.e., conventional $c^{+}$and $z^{+\cdot}$ will be denoted as $[\bar{c}+2 H]^{+}$ and $[\bar{z}+H]^{+}{ }^{\bullet}$, respectively. As summarized in the bond cleavage inserts, sufficient information could be derived from any of these spectra to deduce the peptide sequence. In addition, there are several interesting features associated with these ECD spectra. First, most of the ECD spectra exhibit abundant metalated $c$ - and $z$-fragment ions. However, some nonmetalated $c$-ions could be found in the ECD spectrum of [RGGGVGGGR $+\mathrm{Mg}]^{2+}$. Second, there is a progressive shift in the relative intensity of $\left[\bar{c}_{n}+\mathrm{Cat}-\mathrm{H}\right]^{+}$and $\left[\bar{c}_{n}+\mathrm{Cat}\right]^{+}$ fragments as the size of fragment (i.e., $n$ ) changes. The $\left[\bar{c}_{n}+\mathrm{Cat}\right]^{+}$fragment is generally less abundant than the corresponding $\left[\bar{c}_{n}+\mathrm{Cat}-\mathrm{H}\right]^{+\bullet}$ fragments. Similar shift in the relative intensity of $\left[\bar{z}_{n}+\mathrm{Cat}-\mathrm{H}\right]^{+\bullet}$ and $\left[\bar{z}_{n}+\right.$ Cat $]^{+}$fragments was also found. The $\left[\bar{z}_{n}+\mathrm{Cat}-\mathrm{H}\right]^{+} \cdot$ fragment is generally less abundant than the corresponding $\left[\bar{z}_{n}+c a t\right]^{+}$fragments. This is in contrast to the ECD of the protonated peptide (data not shown) in which the $\left[\bar{c}_{n}+2 \mathrm{H}\right]^{+}$is always much larger than the corresponding $\left[\bar{c}_{n}+H\right]^{+\bullet}$ (and $\left[\bar{z}_{n}+H\right]^{+} \gg\left[\bar{z}_{n}+\right.$ $2 \mathrm{H}]^{+}$). Third, there are striking similarities among ECD spectra of peptide metalated with $\mathrm{Ca}^{2+}, \mathrm{Ba}^{2+}$, and $\mathrm{Sr}^{2+}$. $\left[\bar{c}_{7}+\mathrm{Cat}\right]^{+}$was found to be the most intense fragment ions. For peptide metalated with $\mathrm{Mg}^{2+},\left[\bar{c}_{5}+\mathrm{Cat}\right]^{+}$was, however, the predominant fragment ions. Fourth, internal fragment ions originated from multiple backbone 

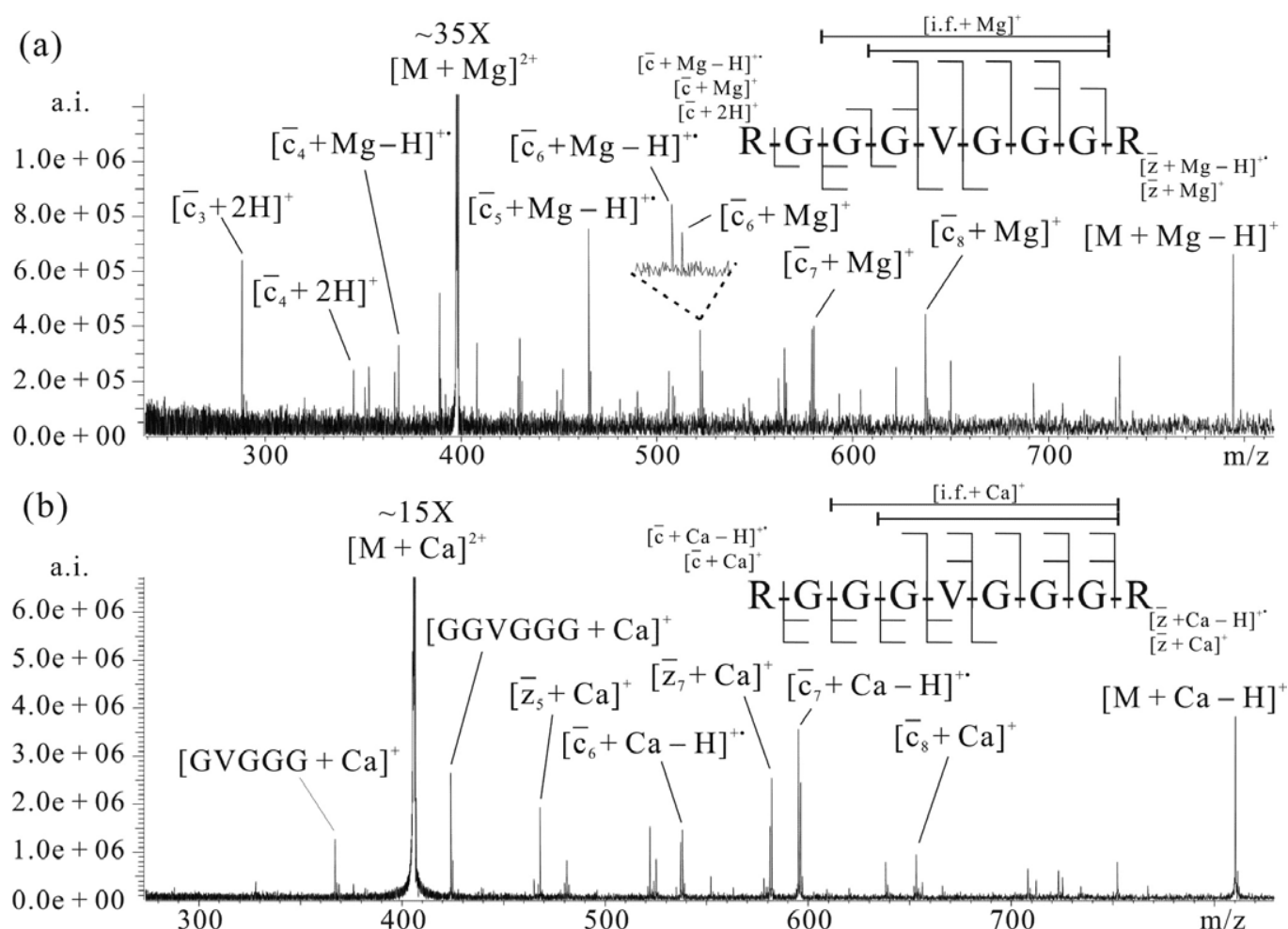

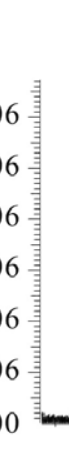

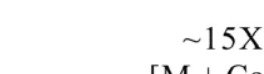

$\sim 15 \mathrm{X}$
$[\mathrm{M}+\mathrm{Ca}]^{2+}$

$\underset{[\bar{c}+\mathrm{Ca}-\mathrm{H}]^{*}}{[\overline{\mathrm{c}}+\mathrm{Ca}]^{*}}$

(c)

a.i.
$1.6 \mathrm{e}+06$
$1.2 \mathrm{e}+06$
$8.0 \mathrm{e}+05$
$4.0 \mathrm{e}+05$
$0.0 \mathrm{e}+00$

(d)

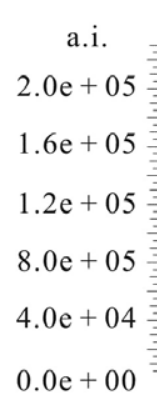

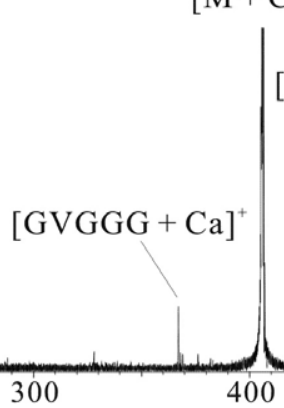

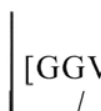

$\stackrel{[\text { i.f. }+\mathrm{Ca}]^{+}}{\longmapsto \neg}$ $\mathrm{m} / \mathrm{z}$

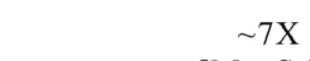

$\sim 7 \mathrm{X}$
$\mathrm{M}+\mathrm{Sr}]^{2+}$
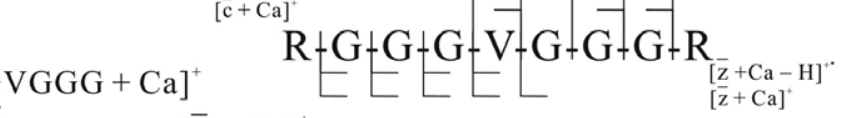

$$
\left[\overline{\mathrm{z}}_{5}+\mathrm{Ca}\right]^{+}\left[\overline{\mathrm{z}}_{7}+\mathrm{Ca}\right]^{+}\left[\overline{\mathrm{c}}_{7}+\mathrm{Ca}-\mathrm{H}\right]^{+}
$$

$\left.\left|\left[\overline{\mathrm{c}}_{6}+\mathrm{Ca}-\mathrm{H}\right]^{+}\right\rangle\right|^{\prime}\left[\overline{\mathrm{c}}_{8}+\mathrm{Ca}\right]^{+}$

$[\mathrm{M}+\mathrm{Ca}-\mathrm{H}]^{+}$
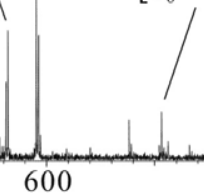

$[\overline{\mathrm{c}}+\mathrm{Sr}-\mathrm{H}]^{+*}$
$[\overline{\mathrm{c}}+\mathrm{Sr}]^{+}$

$\longmapsto\left[^{[\text {i.f. }+ \text { Sr] }}\right.$

$\mathrm{m} / \mathrm{z}$

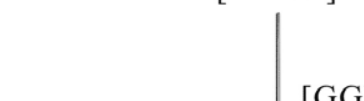

$[\mathrm{GGVGGG}+\mathrm{Sr}]^{+}$

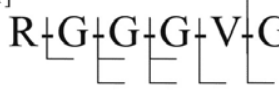

$\mathrm{V}-\mathrm{G}+\mathrm{G}+\mathrm{G}+\mathrm{R}$

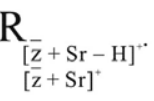

$[\mathrm{GVGGG}+\mathrm{Sr}]^{+}$

$/\left[\overline{\mathrm{z}}_{5}+\mathrm{Sr}\right]^{+}$

$\left[\overline{\mathrm{z}}_{7}+\mathrm{Sr}\right]^{+}$ $\left[\overline{\mathrm{c}}_{7}+\mathrm{Sr}-\mathrm{H}\right]^{+*}$

$[\mathrm{M}+\mathrm{Sr}-\mathrm{H}]^{+}$

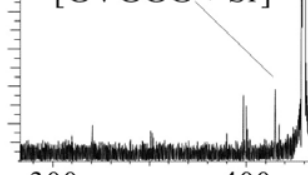

$\left[\overline{\mathrm{Z}}_{8}+\mathrm{Sr}-\mathrm{H}\right]^{+}$

$/\left[\overline{\mathrm{c}}_{8}+\mathrm{Sr}\right]^{+}$

300

400

700

800

$\mathrm{m} / \mathrm{z}$

$\sim 12 \mathrm{X}$

$[\mathrm{M}+\mathrm{Ba}]^{2+}$

500

600

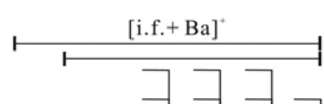

$[\overline{\mathrm{c}}+\mathrm{Ba}-\mathrm{H}]$

$\mathrm{R}+\mathrm{G}+\mathrm{G}+\mathrm{G}+\mathrm{V}-\mathrm{G}+\mathrm{G}+\mathrm{G}+\mathrm{R}$

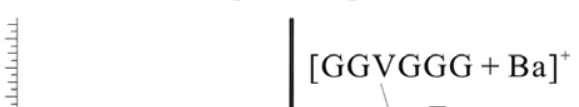

EE E E $\mathrm{R}^{[\bar{z}+\mathrm{Ba}-\mathrm{H}]}\left[\mathrm{z}^{\bar{z}+\mathrm{Ba}]^{*}}\right.$ 青 $[\mathrm{GVGGG}+\mathrm{Ba}]^{+}$

$\left[\overline{\mathrm{z}}_{5}+\mathrm{Ba}\right]^{+}$

$\left[\overline{\mathrm{z}}_{7}+\mathrm{Ba}\right]^{+}$
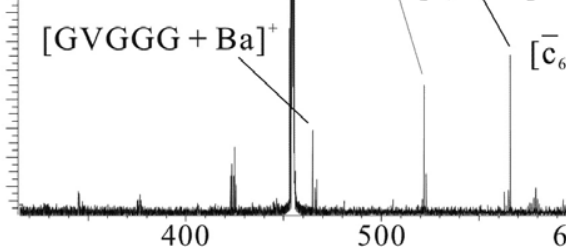

$\left[\mathrm{Z}_{7}+\mathrm{B}\right.$

$\mathrm{Ba}^{+}$

$\mathrm{Ba}-\mathrm{H}]$

(M)

$\mathrm{M}+\mathrm{Ba}-\mathrm{H}]^{+}$

Figure 1. Typical ECD mass spectra of RGGGVGGGR metalated with (a) $\mathrm{Mg}^{2+}$, (b) $\mathrm{Ca}^{2+}$, (c) $\mathrm{Sr}^{2+}$ and (d) $\mathrm{Ba}^{2+}$. "I.f." refers to the internal fragment ions.

cleavages at $\mathrm{N}$ - and C-terminal sides of the metalated peptide ions were observed in the all cases. Because of the mass redundancy, these internal fragment ions could be generated by either multiple $\mathrm{C}(\mathrm{O})-\mathrm{N}$ cleavages or multiple $\mathrm{N}-\mathrm{C}_{\alpha}$ cleavages. Because of the ab- sence of b- and y-type fragment ions, these internal fragments were tentatively attributed to latter case. Intuitively, the occurrence of internal fragments provides supportive evidence for the free-radical cascade mechanism provided by Leymarie and coworkers [36]. 
Table 2. Assignment of peaks in ECD spectrum of RGGGVGGGR metalated with $\mathrm{Mg}^{2+}$

\begin{tabular}{|c|c|c|c|c|}
\hline & Theoretical mass & Experimental mass & $\mathrm{S} / \mathrm{N}$ & Error in ppm \\
\hline$[\mathrm{M}+\mathrm{Mg}-\mathrm{H}]^{+}$ & 794.3861 & 794.3841 & 9.1 & -2.5 \\
\hline$[\mathrm{M}+\mathrm{Mg}-\mathrm{H}]^{+}-\mathrm{HN}-\mathrm{C}\left(\mathrm{NH}_{2}\right)_{2}$ & 736.3456 & 736.3485 & 2.8 & 3.9 \\
\hline Unidentified & - & 650.2900 & 2.9 & - \\
\hline$\left[\bar{c}_{8}+\mathrm{Mg}\right]^{+}$ & 637.3015 & 637.3086 & 7.5 & 11.1 \\
\hline$\left[\bar{z}_{8}+\mathrm{Mg}-\mathrm{H}\right]^{+\bullet}$ & 622.2668 & 622.2691 & 4.0 & 3.7 \\
\hline$\left[\bar{c}_{7}+\mathrm{Mg}\right]^{+}$ & 580.2800 & 580.2841 & 8.5 & 6.9 \\
\hline$\left[\bar{c}_{7}+\mathrm{Mg}-\mathrm{H}\right]^{+\bullet}$ & 579.2722 & 579.2645 & 6.5 & -13.3 \\
\hline$\left[\bar{z}_{7}+\mathrm{Mg}-\mathrm{H}\right]^{+\bullet}$ & 565.2453 & 565.2430 & 3.8 & -4.2 \\
\hline$\left[\bar{c}_{6}+\mathrm{Mg}-\mathrm{H}\right]^{+\bullet}$ & 522.2508 & 522.2464 & 6.6 & -8.4 \\
\hline$\left[\bar{z}_{6}+\mathrm{Mg}-\mathrm{H}\right]^{+\bullet}$ & 508.2239 & 508.2194 & 2.3 & -8.8 \\
\hline$\left[\bar{c}_{5}+\mathrm{Mg}-\mathrm{H}\right]^{+\bullet}$ & 465.2293 & 465.2265 & 13.9 & -6.0 \\
\hline$\left[\bar{z}_{5}+\mathrm{Mg}\right]^{+}$ & 452.2102 & 452.2180 & 3.4 & 17.1 \\
\hline Unidentified & - & 430.1733 & 4.7 & - \\
\hline GGVGGG + Mg & 408.1602 & 408.1563 & 7.7 & -9.5 \\
\hline$[\mathrm{M}+\mathrm{Mg}]^{2+}$ & 397.6970 & 397.6969 & 572.5 & -0.1 \\
\hline Unidentified & - & 389.1940 & 6.8 & - \\
\hline$\left[\bar{c}_{4}+\mathrm{Mg}-\mathrm{H}\right]^{+\bullet}$ & 366.1609 & 366.1543 & 4.6 & -18.1 \\
\hline$\left[\bar{z}_{4}+\mathrm{Mg}\right]^{+}$ & 353.1418 & 353.1404 & 5.3 & -4.1 \\
\hline GVGGG + Mg & 351.1388 & 351.1395 & 4.9 & 2.0 \\
\hline$\left[\bar{c}_{4}+2 \mathrm{H}\right]^{+}$ & 345.1993 & 345.1983 & 4.4 & -3.0 \\
\hline$\left[\bar{c}_{3}+2 \mathrm{H}\right]^{+}$ & 288.1778 & 288.1785 & 13.2 & 2.3 \\
\hline
\end{tabular}

However, further experiments would be needed to clarify the structures and their formation pathways.

\section{ECD spectra of NGGGWGGGN Metalated with Alkaline-Earth Metal Ions}

Figure $2 \mathrm{a}-\mathrm{d}$ show typical ECD mass spectra of NGGGWGGGN metalated with $\mathrm{Mg}^{2+}, \mathrm{Ca}^{2+}, \mathrm{Sr}^{2+}$, and $\mathrm{Ba}^{2+}$, respectively. The mass assignments of the corresponding $\mathrm{Mg}$-metalated species are given in Table 3. It was internally calibrated using $[M+$ $\mathrm{Cat}]^{2+},[\mathrm{M}+\mathrm{Cat}-\mathrm{H}]^{+}$, and $\left[\bar{z}_{n}+\mathrm{Cat}\right]^{+}$. In contrast to the cases of RGGVGGGR, all fragment ions observed in these ECD spectra are metalated. The corresponding nonmetalated $c$-ions observed in ECD spectrum of [RGGGVGGGR $+\mathrm{Mg}^{2+}$ are absent in the ECD spectrum of [NGGGWGGGW $+\mathrm{Mg}^{2+}$. However, the abnormal intensity ratios of $\left[\bar{c}_{n}+\mathrm{Cat}+\right.$ $H]^{+\bullet} /\left[\bar{c}_{n}+\mathrm{Cat}+2 \mathrm{H}\right]^{+}$(and $\left[\bar{z}_{n}+\mathrm{Cat}-\mathrm{H}\right]^{+\bullet} /\left[\bar{z}_{n}+\right.$ Cat $]^{+}$) fragments remain a general feature in the ECD spectra of metalated NGGGWGGGN. Due, presumably, to the lack of basic functional group except the $\mathrm{N}$-terminal amino group, we failed to generate doubly-protonated NGGGWGGGN precursor ions for ECD experiment. Therefore, the corresponding ECD spectrum is not available for comparison. Apart from the $c$ - and $z$-type fragment ions resulting from backbone cleavages, the ECD spectra of metalated NGGGWGGGN show some characteristic fragment ions corresponding to the secondary fragmentation of both $\left[\bar{z}_{n}+\mathrm{Cat}-\mathrm{H}\right]^{+\bullet}$ and $\left[\bar{c}_{n}+\mathrm{Cat}-\mathrm{H}\right]^{+\bullet}$ species. Losses of odd-electron side chain of the tryptophan residue $(-116.1 \mathrm{Da})$ were observed [36]. In addition, the ECD spectra of metalated NGGGWGGGN produced more extensive internal frag- ment ions in comparison with that of metalated RGGGVGGGR.

\section{Discussion}

\section{Nonmetalated c-Ions}

The observation of nonmetalated $c$-ions is interesting as the charges of the precursor are presumably localized on the metal ions. The residual charge should reside on the metal ion even after electron reduction of the divalent metal ions. A plausible explanation for the formation of nonmetalated $c$-ions might be related to the charge-transfer reaction between the "hot" monovalent metal ions and the peptide ions. Since the second ionization potential of magnesium is the highest among the alkaline earth metals (see Table 1), it is perhaps not surprising to find that only $\mathrm{Mg}^{2+}$ metalated peptide showed these nonmetalated fragments upon ion/electron recombination. However, all nonmetalated c-ions show masses corresponding to the usual c-fragment ions observed in the ECD spectrum of protonated peptides, i.e., there is a surplus of two hydrogen atoms in the $\mathrm{N}$-terminal fragment after homolytic cleavage of the $\mathrm{N}-\mathrm{C}_{\alpha}$ linkage. This observation pointed to an alternative neutralization pathway involving the presence of mobile proton(s) within the precursor ions before electron capture.

It is well-known in mass spectrometric analysis that multiple adduction of metal ions, $\mathrm{m}(\mathrm{Cat})^{\mathrm{n}+}$, onto the peptide molecules can lead to an ion, $[\mathrm{M}+\mathrm{mCat}]^{\mathrm{z}+}$, in which the charge number being much smaller then the total charges carried by the metal ions, i.e., $\mathrm{z} \ll\left(m^{*} n\right)$. As deduced from the mass shift of the resultant ion, the charge deficit is compensated by the elimination of 


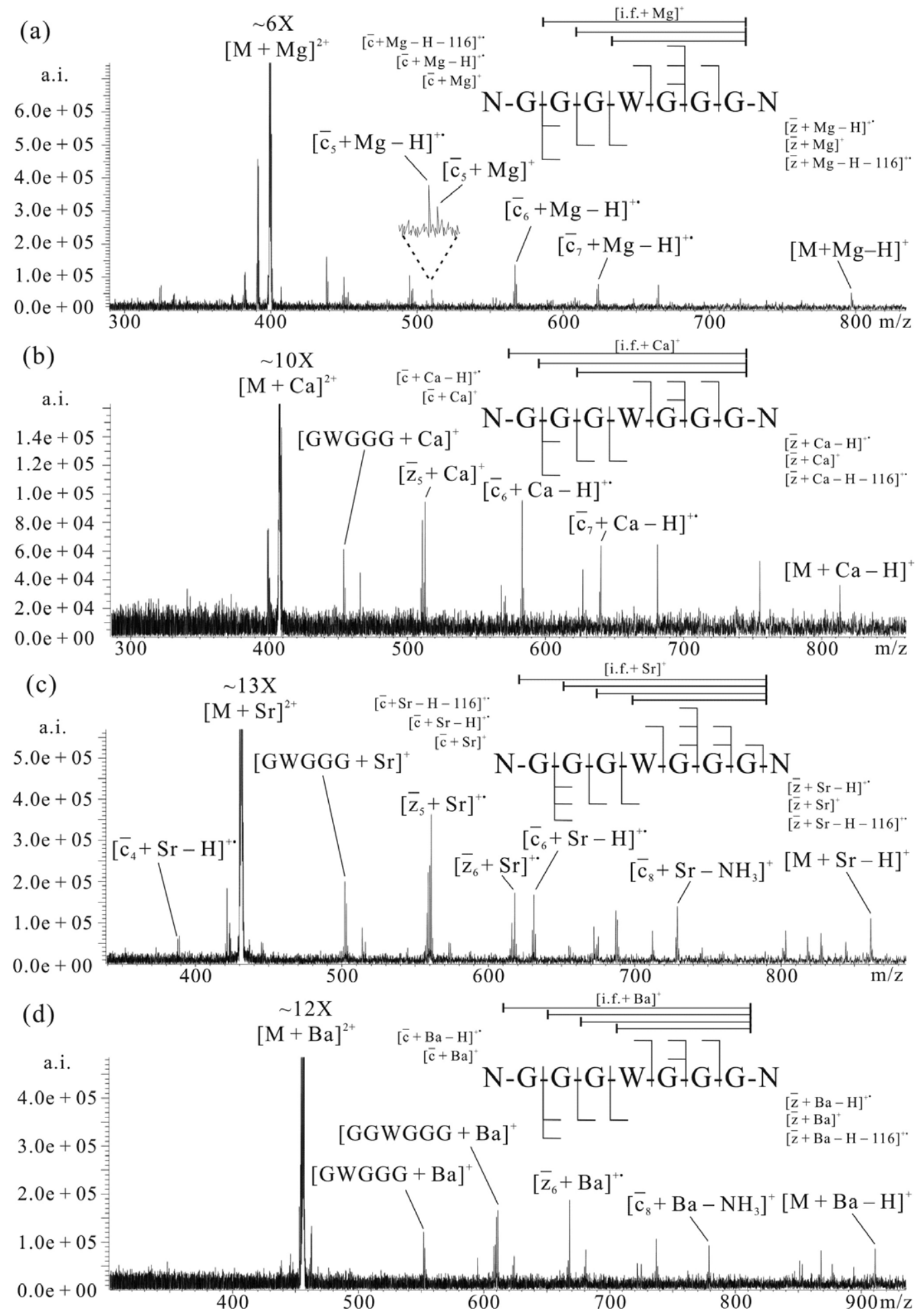

Figure 2. Typical ECD mass spectra of NGGGVGGGN metalated with (a) $\mathrm{Mg}^{2+}$, (b) $\mathrm{Ca}^{2+}$, (c) $\mathrm{Sr}^{2+}$ and (d) $\mathrm{Ba}^{2+}$. "I.f." refers to the internal fragment ions.

equivalent number of protons, i.e., $\left[\left(m^{*} n\right)-z\right] H$, from the peptide molecule [37]. In fact, the electrospray ionization mass spectrum of $\mathrm{RG}_{3} \mathrm{VG}_{3} \mathrm{R}$ obtained in the presence of strontium acetate showed several doublycharged peptide molecular ions, $[\mathrm{M}+\mathrm{mCat}-(2 \mathrm{~m}-$
2)H ${ }^{2+}$, with $\mathrm{m}$ ranging from 1 to 3 (data not shown). Binding of metal ions onto the peptide backbone has been extensively studied $[38,39]$. In each of the amide group, there are two potential binding atoms, the oxygen and nitrogen, for complexation of metal ions. 
Table 3. Assignment of peaks in ECD spectrum of NGGGWGGGN metalated with $\mathrm{Mg}^{2+}$

\begin{tabular}{|c|c|c|c|c|}
\hline & Theoretical mass & Experimental mass & $\mathrm{S} / \mathrm{N}$ & Error in ppm \\
\hline$[\mathrm{M}+\mathrm{Mg}-\mathrm{H}]^{+}$ & 797.2812 & 797.2806 & 4.6 & -0.7 \\
\hline$\left[\bar{c}_{8}+\mathrm{Mg}\right]^{+}$ & 665.2277 & 665.2248 & 4.9 & -4.3 \\
\hline$\left[\bar{c}_{7}+\mathrm{Mg}-\mathrm{H}\right]^{+\bullet}$ & 624.2249 & 624.2229 & 3.1 & -3.3 \\
\hline$\left[\bar{c}_{6}+\mathrm{Mg}\right]^{+}$ & 568.2113 & 568.2126 & 3.8 & 2.2 \\
\hline$\left[\bar{c}_{6}+\mathrm{Mg}-\mathrm{H}\right]^{+\bullet}$ & 567.2035 & 567.1998 & 6.7 & -6.6 \\
\hline$\left[\bar{c}_{5}+\mathrm{Mg}-\mathrm{H}\right]^{+\bullet}$ & 510.1820 & 510.1874 & 2.6 & 10.6 \\
\hline$\left[\bar{z}_{5}+\mathrm{Mg}\right]^{+}$ & 497.1630 & 497.1635 & 3.2 & 1.2 \\
\hline GGWGGG + Mg & 495.1711 & 495.1674 & 5.0 & -7.6 \\
\hline$\left[\bar{z}_{7}+\mathrm{Mg}-\mathrm{H}\right]^{+\bullet}-\mathrm{C}_{8} \mathrm{H}_{6} \mathrm{~N}^{\bullet}$ & 494.1475 & 494.1389 & 2.1 & -17.4 \\
\hline Unidentified & - & 450.1468 & 4.4 & - \\
\hline GWGGG + Mg & 438.1497 & 438.1482 & 8.1 & -3.2 \\
\hline$[\mathrm{M}+\mathrm{Mg}]^{2+}$ & 399.1442 & 399.1440 & 249.1 & -0.6 \\
\hline Unidentified & - & 391.1317 & 7.3 & - \\
\hline$W G G G+M g$ & 381.1282 & 381.1285 & 2.2 & 0.9 \\
\hline$\left[\bar{c}_{4}+\mathrm{Mg}\right]^{+}$ & 325.1105 & 325.1113 & 3.5 & 2.4 \\
\hline$\left[\bar{c}_{4}+\mathrm{Mg}-\mathrm{H}\right]^{+\bullet}$ & 324.1027 & 324.1020 & 2.9 & -2.2 \\
\hline
\end{tabular}

Carbonyl oxygen had previously been identified to bind with alkali and alkaline-earth metal ions. This is consistent with molecular dynamic simulation studies that alakine-earth metal ion is commonly solvated by multiple amido carbonyl oxygen atoms [40,41]. Both experimental and theoretical results have shown that metalation at the amide oxygen increases the doublebond character in the $\mathrm{C}-\mathrm{N}$ bond and, thus, enhances the acidity of the amide hydrogen [39, 42]. To get more insight onto the effect of metal ion coordination on the acidity of the amide hydrogen, theoretical studies using ab initio calculation at B3-PMP2/6-311 + + G(3df,2p)/ / B3LYP/6-31 ++ G(d,p) level on model system were performed. N-methyl glycyl-glycinamide was used as a truncated peptide model, and $\mathrm{Mg}^{2+}$ was used as the metal ion. The energies of the model reactions were summarized in Table 4.

Scheme 1 summarizes the optimized geometries for the reactants, transition-state, and products for intramolecular proton transfer reaction within the $\mathrm{N}$-methyl glycyl-glycinamide in the (a) absence, and (b) presence of $\mathrm{Mg}^{2+}$ ion. 1a and 2a represent the conformers of interest for the neutral and $\mathrm{Mg}^{2+}$ bounded N-methyl glycyl-glycinamide, respectively. 1a adopts a conformation in which the backbone amide is simultaneously hydrogen bonded with the carbonyl oxygen and the terminal amino group. Intramolecular proton transfer from the amide to the $\mathrm{N}$-terminal amino group leads to the charge separation. This reaction was expected to be thermodynamically unfavorable and was therefore computed by stepwise reduction of the $\mathrm{H} \cdots \mathrm{N}$ distance. It requires $114 \mathrm{kJmol}^{-1}$ to change from $\mathbf{1 a}$ to $\mathbf{1 b}$. $\mathbf{2 a}$ adopts a conformation in which the carbonyl oxygen atoms were coordinated with the $\mathrm{Mg}^{2+}$. In the presence of the $\mathrm{Mg}^{2+}$, intramolecular proton transfer from the amide to the N-terminal amino group is slightly endothermic and requires only low activation energy, $\Delta \mathrm{H}_{\mathrm{rxn}}$ $=+5 \mathrm{kJmol}^{-1}$ and $\mathrm{E}_{\mathrm{TS}}=+15 \mathrm{kJmol}^{-1}$ for $\mathbf{2 a} \rightarrow$ TS2ab $\rightarrow \mathbf{2 b}$ (Scheme $\mathbf{1}$ ). In the presence of high proton affinity functionalities, such as lysine, arginine, and histidine side chains, the metal coordinated peptide ions should, therefore, take a zwitterion form in which the backbone amide group(s) and/or the C-terminal carboxylic acid group are deprotonated, and the basic amino acid side chains are protonated. The precursor ion should, therefore, be represented by three isomeric forms, namely [M $+\mathrm{Cat}^{2+},[(\mathrm{M}+\mathrm{Cat}-\mathrm{H})+\mathrm{H}]^{2+}$, and $[(\mathrm{M}+\mathrm{Cat}-2 \mathrm{H})$ $+2 \mathrm{H}]^{2+}$. The relative abundance of these isomeric precursor ions should depend on the nature of the metal ions and the availability of high proton affinity amino acid residues.

Having established the presence of mobile proton(s) within the precursor ion, the formation of nonmetalated $c$-ions can readily be explained. Table 5 summarizes all ion-electron recombination arrangements for the three aforementioned structural isomeric precursor ions and

Table 4. Energies of the model reactions

\begin{tabular}{lcrr} 
& \multicolumn{2}{c}{ Relative energy $^{\mathrm{a}}$} \\
\cline { 2 - 4 } & \multicolumn{2}{c}{$6-31++\mathrm{G}(\mathrm{d}, \mathrm{p})$} & \multicolumn{2}{c}{$6-311++\mathrm{G}(3 \mathrm{df}, 2 \mathrm{p})$} \\
\cline { 2 - 4 } Species/reaction & B3LYP & B3LYP & PMP2 \\
\hline \hline $1 \mathrm{a} \rightarrow 1 \mathrm{~b}$ & 115 & 118 & 110 \\
$2 \mathrm{a} \rightarrow 2 \mathrm{~b}$ & 9 & 11 & 0 \\
$2 \mathrm{a} \rightarrow$ Ts2ab & 16 & 19 & 11 \\
\hline
\end{tabular}

aIn units of $\mathrm{kJmol}^{-1}$ at $0 \mathrm{~K}$ including B3LYP/6-31(d,p) zero-point energy corrections. 
(a)

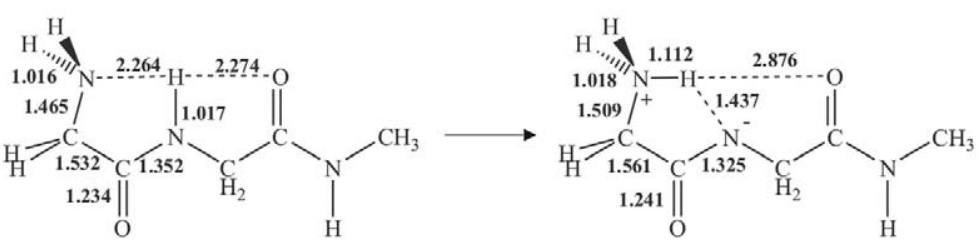

$1 \mathrm{a}$

$1 \mathrm{~b}$

(b)

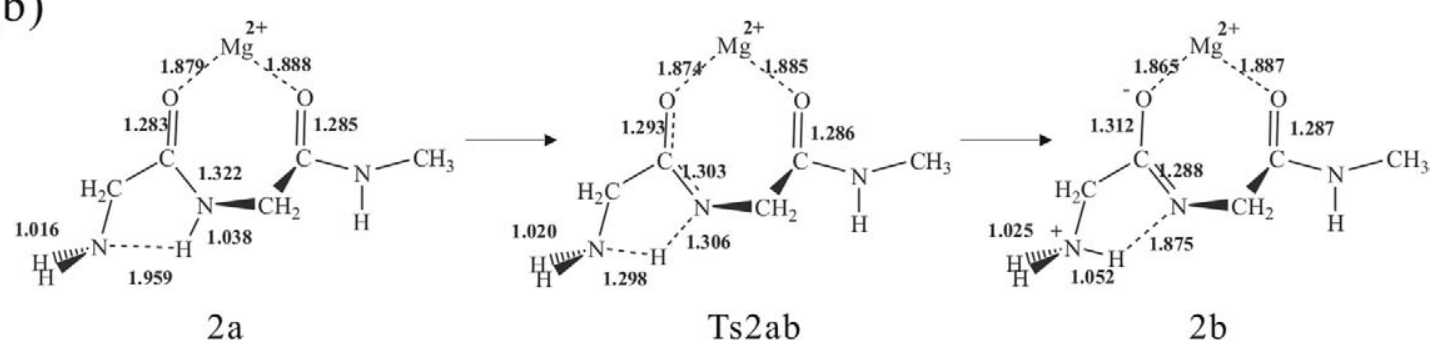

Scheme 1

their possible types of fragment ions. For the precursor ion isomer with no mobile proton, only metalated fragment ions, i.e., $[\bar{c}+\mathrm{Cat}]^{+}$and $[\bar{z}+\mathrm{Cat}]^{+}$, can be generated. It is clearly demonstrated that the observed $[\bar{c}+2 \mathrm{H}]^{+}$can only be generated by the precursor ions with two mobile protons. Among the various alkaline earth metal ions, it is believed that only $\mathrm{Mg}^{2+}$ could have enough charge density to induce the formation of two mobile protons within the RGGGVGGGR molecules and forms the $[(\mathrm{M}+\mathrm{Mg}-2 \mathrm{H})+2 \mathrm{H}]^{2+}$ precursor ion. Only [RGGGVGGGR $+\mathrm{Mg}-2 \mathrm{H})+2 \mathrm{H}]^{2+}$ could, therefore, generate nonmetalated $c$-fragments. In the absence of basic amino acid residues, even $\mathrm{Mg}^{2+}$ could not induce two mobile protons within the NGGGWGGGN molecules. This is reflected from the fact that none of the metalated NGGGWGGGN species could generate nonmetalated fragment ions. Since peptides metalated with alkaline earth metal ions yield very similar ECD spectra, it is postulated that metal-ion reduction under the current electron capture dissociation conditions did not play any significant role in inducing the fragmentation.

Intensity Ratios of $\left[\bar{c}_{n}+\mathrm{Cat}-\mathrm{H}\right]^{+\bullet} /\left[\bar{c}_{n}+\mathrm{Cat}\right]^{+}$ and $\left[\bar{z}_{n}+\mathrm{Cat}\right]^{+} /\left[\bar{z}_{n}+\mathrm{Cat}-\mathrm{H}\right]^{+}$Fragments

Even though there is no distinctive effect of the alkaline earth metal ions on the fragmentation efficiency of the model peptides under ECD conditions, there exist some interesting spectral features. A noticeable difference between the ECD spectra of the protonated (spectrum not shown) and metalated peptides is related to the intensity ratios of $\left[\bar{c}_{n}+\mathrm{Cat}-\mathrm{H}\right]^{+\bullet} /\left[\bar{c}_{n}+\mathrm{Cat}\right]^{+}$and $\left[\bar{z}_{n}\right.$ $+\mathrm{Cat}]^{+} /\left[\bar{z}_{n}+\mathrm{Cat}-\mathrm{H}\right]^{+\bullet}$ species. Tables 6 and 7 summarize this information as extracted from the ECD spectra of metalated RGGGVGGGR and NGGG-
WGGGN. The black bars represent the peak intensities of $\left[\bar{c}_{n}+\mathrm{Cat}\right]^{+}$and $\left[\bar{z}_{n}+\mathrm{Cat}-\mathrm{H}\right]^{+}$species; the white bars represent the peak intensities of $\left[\bar{c}_{n}+\mathrm{Cat}-\mathrm{H}\right]^{+} \cdot$ and $\left[\bar{z}_{n}+\mathrm{Cat}\right]^{+}$species. The peak intensities of the corresponding fragment ions obtained from the ECD spectrum of doubly-protonated RGGGVGGGR are included for comparison. As mentioned in previous section, ECD spectrum of doubly-protonated NGGGWGGGN is not available. It is clearly demonstrated that these ratios are similar among the ECD spectra of various metalated peptides and are generally much higher than the equivalent ratios of the fragment ions generated from the protonated peptide. As it is concluded in the previous section that the metal moiety in the precursor ion should take no significant role in the ECD process, the observed differences in these fragment ion ratios are tentatively attributed to the effect of the metal-peptide binding on the relative generation efficiencies of these fragment ions.

Reaction Pathways for the formation
of $\left[\bar{c}_{n}+\mathrm{Cat}-\mathrm{H}\right]^{+}$and $\left[\bar{z}_{n}+\mathrm{Cat}\right]^{+}$

In the past, much of the attention has been focused on the mechanistic aspects of the major dissociation pathway, which accounts for the formation of the $\left[\bar{c}_{n}+2 \mathrm{H}\right]^{+}$ and $\left[\bar{z}_{n}+H\right]^{+\bullet}$ fragments. The prevailing mechanisms involve either the proton-coupled electron-transfer from the hypervalent amino group to the amido carbonyl oxygen [26, 43], or the formation of super-basic amido radical that abstracts a proton from a nearby amino acid residue [44]. In both cases, the formation of labile aminoketyl radicals would induce the characteristics $\mathrm{N}-\mathrm{C}_{\alpha}$ backbone cleavage. Structures and energetics of these reactions have been characterized using high level ab initio calculations [43-45]. However, rel- 
Table 5. A summary of all ion-electron recombination arrangements using the isomeric precursor ions, i.e., $[\mathrm{M}+\mathrm{Cat}]^{2+},[(\mathrm{M}+\mathrm{Cat}$ $-H)+H]^{2+},[(M+C a t-2 H)+2 H]^{2+}$, and their possible types of fragment ions

\begin{tabular}{|c|c|c|c|c|c|}
\hline \multirow{3}{*}{$\begin{array}{l}\text { Site for ion/ } \\
\text { electron } \\
\text { recombination }\end{array}$} & \multicolumn{4}{|c|}{ Precursor ions } & \multirow[b]{3}{*}{ Fragment ions } \\
\hline & {$[M+C a t]^{2+}$} & \multicolumn{2}{|c|}{$[M+(C a t-H)+H]^{2+}$} & \multirow{2}{*}{$\frac{[M+(\mathrm{Cat}-2 \mathrm{H})+2 \mathrm{H}]^{2+}}{\text { Proton }}$} & \\
\hline & Metal ion & Metal ion & Proton & & \\
\hline & $\frac{\bar{c} \bullet}{\text { Cat }^{+\bullet}} \longleftarrow \overline{\bullet \bar{z}}$ & $\frac{\bar{c}^{\bullet}}{(\text { Cat }-H)^{\bullet} H^{+}} \longleftarrow \overline{\bar{z}_{\bar{z}}}$ & $\frac{\bar{c}^{\bullet}}{(\text { Cat }-H)^{+} H^{\bullet}} \longleftarrow \overline{\bullet \bar{z}}$ & $\frac{\bar{c}^{\bullet}}{(\text { Cat }-2 H)^{\bullet} H^{+} H^{\bullet}} \longleftrightarrow \cdot \overline{\bullet_{\bar{z}}}$ & {$\left[\bar{c}+\right.$ Cat $^{+}$} \\
\hline & & & $\frac{\bar{c}^{\bullet}}{(\text { Cat }-H)^{+}} \longleftarrow \frac{H^{\bullet}}{\bullet \bar{z}}$ & $\frac{\bar{c}^{\bullet}}{(\text { Cat }-2 H)^{\bullet} H^{+}} \hookleftarrow \frac{H^{\bullet}}{\bullet \bar{z}}$ & {$[\bar{c}+C a t-H]^{+\bullet}$} \\
\hline & & $\frac{\bar{c}^{\bullet}}{H^{+}} \longleftarrow \frac{(C a t-H)^{\bullet}}{\bullet \bar{z}}$ & & $\frac{\bar{c}^{\bullet}}{H^{+}} \hookleftarrow \frac{(C a t-2 H)^{\bullet} H^{\bullet}}{\bullet \bar{z}}$ & {$[\bar{c}+H]^{+\bullet}$} \\
\hline & & & & $\frac{\bar{c}^{\bullet}}{H^{+} H^{\bullet}} \hookleftarrow \frac{(\text { Cat }-2 H)^{\bullet}}{\bullet \bar{z}}$ & {$[\bar{c}+2 H]^{+}$} \\
\hline & & & $\frac{\bar{c}^{\bullet}}{H^{\bullet}} \mapsto \frac{(\text { Cat }-H)^{+}}{\bullet \bar{z}}$ & $\frac{\bar{c}^{\bullet}}{H^{\bullet}} \longmapsto \frac{(\text { Cat }-2 H)^{\bullet} H^{+}}{\bullet \bar{z}}$ & {$[\bar{z}+\mathrm{Cat}-\mathrm{H}]^{+\bullet}$} \\
\hline & $\stackrel{\bar{c}^{\bullet}}{\longrightarrow} \frac{\mathrm{Cat}^{+\bullet}}{\bullet \bar{z}}$ & $\stackrel{\bar{c}^{\bullet}}{\longrightarrow} \frac{(\text { Cat }-H)^{\bullet} H^{+}}{\bullet \bar{z}}$ & $\stackrel{\bar{c}^{\bullet}}{\longrightarrow} \frac{(\text { Cat }-H)^{+} H^{\bullet}}{\bullet \bar{z}}$ & $\stackrel{\bar{c}^{\bullet}}{\longrightarrow} \frac{(\text { Cat }-2 H)^{\bullet} H^{+} H^{\bullet}}{\bullet \bar{z}}$ & {$[\bar{z}+C a t]^{+}$} \\
\hline & & $\frac{\bar{c}^{\bullet}}{(C a t-H)^{\bullet}} \longmapsto \frac{H^{+}}{\bullet \bar{z}}$ & & $\frac{\bar{c}^{\bullet}}{(\text { Cat }-2 H)^{\bullet} H^{\bullet}} \longmapsto \frac{H^{+}}{\bullet \bar{z}}$ & {$[\bar{z}+H]^{+\bullet}$} \\
\hline & & & & $\frac{\bar{c}^{\bullet}}{(\text { Cat }-2 H)^{\bullet}} \longmapsto \frac{H^{+} H^{\bullet}}{\bullet \bar{z}}$ & {$[\bar{z}+2 H]^{+}$} \\
\hline
\end{tabular}

atively little is known concerning the minor dissociation pathway leading to the formation of the $\left[\bar{c}_{n}+H\right]^{+}$and $\left[\bar{z}_{n}+2 \mathrm{H}\right]^{+}$fragments.

From a survey of the literatures, two fragmentation pathways have been proposed to account for the observation of $\left[\bar{c}_{n}+H\right]^{+}$and $\left[\bar{z}_{n}+2 H\right]^{+}$fragments. Pathway $\mathrm{I}$ involves a two-step reaction in which a hydrogen atom is first attached onto the amido carbonyl oxygen to form the labile aminoketyl radicals and is followed by the cleavage of the $\mathrm{N}$-terminal side $\mathrm{N}-\mathrm{C}_{\alpha}$ linkage. Pathway II involves a direct substitution reaction in which the attachment of a hydrogen atom onto an $\alpha$-carbon causes a simultaneous cleavage of the adjacent $\mathrm{N}-\mathrm{C}_{\alpha}$ linkage. To account for the observed intensity ratios of $\left[\bar{c}_{n}+\mathrm{Cat}-H\right]^{+\bullet} /\left[\bar{c}_{n}+\mathrm{Cat}\right]^{+}$and $\left[\bar{z}_{n}+\right.$ $\mathrm{Cat}^{+} /\left[\bar{z}_{n}+\mathrm{Cat}-\mathrm{H}\right]^{+\bullet}$ species, these reaction pathways were evaluated computationally using ab initio calculations at B3-PMP2/6-311 ++ G(3df,2p)// B3LYP/6-31 ++ G(d,p) level using a simple peptide model, i.e., N-methyl N-acetylglycl-glycinamide. The energies of the model reactions are summarized in Table 8 .

Because of the multiple functions of the model system, many different conformational isomers are possible. 3a, 3b, and $3 \mathbf{c}$ are three isomers of interest (Scheme 2). Common to all isomers, both the C-terminal and N-terminal amido nitrogen adopts a $\mathrm{sp}^{2}$ hybridization with the unpaired electron delocalizing along the adjacent $\mathrm{C}(\mathrm{O}) \pi$-network. For isomer 3a, both N-terminal and C-terminal amide groups adopt trans-configurations. The C-terminal amide hydrogen is hydrogen bonded with the N-terminal carbonyl oxygen through a seven-membered ring. For isomer $\mathbf{3 b}$, the C-terminal amide group adopts a cis-configuration; whereas the 
Table 6. A summary of relative intensities of $\left[\bar{c}_{n}+\mathrm{Cat}\right]^{+},\left[\bar{c}_{n}+\mathrm{Cat}-H\right]^{+},\left[\bar{z}_{n}+\mathrm{Cat}-H\right]^{+} \bullet$ and $\left[\bar{z}_{n}+\mathrm{Cat}\right]^{+}$as obtained from the ECD spectra of metalated RGGGVGGGR. The black bar represent the intensity of $\left[\bar{c}_{n}+\mathrm{Cat}\right]^{+}$or $\left[\bar{z}_{n}+\mathrm{Cat}-\mathrm{H}\right]^{+\bullet}$ ions and the white bar represent the intensity of $\left[\bar{c}_{n}+\mathrm{Cat}-\mathrm{H}\right]^{+} \cdot$ or $\left[\bar{z}_{n}+\mathrm{Cat}\right]^{+}$ions

\begin{tabular}{|c|c|c|c|c|c|c|c|c|}
\hline & \multicolumn{5}{|c|}{ Precursor ions } & & \multicolumn{2}{|c|}{ Precursor ions ${ }^{b}$} \\
\hline & $\mathrm{n}^{\mathrm{a}}$ & {$[\mathrm{M}+\mathrm{Mg}]^{2+}$} & {$[\mathrm{M}+\mathrm{Ca}]^{2+}$} & {$[\mathrm{M}+\mathrm{Sr}]^{2+}$} & {$[\mathrm{M}+\mathrm{Ba}]^{2+}$} & & $\mathrm{n}^{\mathrm{a}}$ & {$[\mathrm{M}+2 \mathrm{H}]^{2+}$} \\
\hline \multirow[t]{5}{*}{$c$-type fragment ions } & 8 & - & a & a & $\square$ & $c$-type fragment ions & 8 & \\
\hline & 7 & & & r & & & 7 & \\
\hline & 6 & C & $\square$ & $\square$ & $\square$ & & 6 & \\
\hline & 5 & L & $\bar{\square}$ & $\bar{\square}$ & $\square$ & & 5 & \\
\hline & 4 & $\square$ & [ & & & & 4 & \\
\hline \multirow[t]{5}{*}{$z$-type fragment ions } & 8 & & $\mathbf{0}$ & a & $\square$ & $z$-type fragment ions & 8 & \\
\hline & 7 & - & & 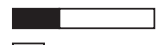 & 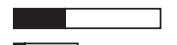 & & 7 & \\
\hline & 6 & $\square$ & $\square$ & $\square$ & $\square$ & & 6 & \\
\hline & 5 & $\square$ & $\square$ & $\square$ & $\square$ & & 5 & \\
\hline & 4 & $\square$ & $\square$ & $\square$ & & & 4 & \\
\hline
\end{tabular}

${ }^{a} \mathrm{n}$ represents the number of remaining amino acid residues in the fragments.

${ }^{\mathrm{b}}\left[\bar{c}_{n}+2 H\right]^{+},\left[\bar{c}_{n}+H\right]^{+\bullet},\left[\bar{z}_{n+} H\right]^{+\bullet}$ and $\left[\bar{z}_{n}+2 H\right]^{+}$obtained from the ECD spectra of doubly-protonated RGGGVGGGR are included for comparison.

N-terminal amide group adopts a trans-configuration. Both $\mathrm{N}$ - and C-terminal amide hydrogen atoms are hydrogen bonded to the C-terminal carbonyl oxygen. For isomer 3c, both $\mathrm{N}$ - and C-terminal amide groups adopt cis-configurations and the amide hydrogen atoms are hydrogen bonded with the carbonyl oxygen within their amide groups. Thermodynamically, isomer $\mathbf{3 a}$ is $20 \mathrm{kJmol}^{-1}$ more stable than isomer $\mathbf{3 b}$, which in turn is $8 \mathrm{kJmol}^{-1}$ more stable than isomer $3 \mathrm{c}$.

To determine the likelihood of the proposed mechanisms for the formation of $\left[\bar{c}_{n}+\mathrm{H}^{+}\right]^{\bullet}$ and $\left[\bar{z}_{n}+2 \mathrm{H}\right]^{+}$ fragments, the energies for the major dissociation pathway, i.e., the one leading to the cleavage of $\mathrm{N}-\mathrm{C}_{\alpha}$ linkage, were first computed using the model system. Conformer $\mathbf{3 b}$ was selected as a starting geometry for this study because of the accessibility of the N-terminal amido carbonyl oxygen. In accordance with the mechanism involving the proton-coupled electron-transfer, the amido carbonyl oxygen should be a hydrogen bonded with the initial charge carrier. In the present calculation, a hydrogen atom was added directly onto the $\mathrm{N}$-terminal amido carbonyl oxygen of isomer $3 \mathbf{b}$ to form 3d. This reaction is exothermic $\left(\Delta \mathrm{H}_{\mathrm{rxn}}=35\right.$ $\mathrm{kJmol}^{-1}$ ). The carbon radical then initiates the expected $\mathrm{N}-\mathrm{C}_{\alpha}$ cleavage through a transition-state (TS3de). This cleavage reaction is endothermic and requires moderate activation energy, $\Delta \mathrm{H}_{\mathrm{rxn}}=+27 \mathrm{kJmol}^{-1}$ and $\mathrm{E}_{\mathrm{TS}}=+70$ $\mathrm{kJmol}^{-1}$ for $\mathbf{3 d} \rightarrow$ TS3de $\rightarrow \mathrm{CH}_{3} \mathrm{C}(\mathrm{OH})=\mathrm{NH}+3 \mathbf{e}$ (Scheme 3).

Scheme 4 shows the optimized geometries for the reactant, transition-state, intermediates and products for dissociation Pathway I. Isomer 3a was used as the starting geometry. Attachment of a hydrogen onto the C-terminal amido carbonyl oxygen leads to the formation of the labile aminoketyl radicals, $3 \mathbf{f}$. Cleavage of the target $\mathrm{N}-\mathrm{C}_{\alpha}$ linkage leads to the formation of radicalneutral complex, $3 \mathrm{~g}$, through the transition-state, TS3fg. On top of the expected $\mathrm{N}-\mathrm{C}_{\alpha}$ cleavage, $3 \mathrm{~g}$ has an additional hydrogen transfer from the C-terminal $\mathrm{N}-\mathrm{H}$ to the N-terminal amido carbonyl oxygen. Close inspec-

Table 7. A summary of relative intensities of $\left[\bar{c}_{n}+\mathrm{Cat}\right]^{+},\left[\bar{c}_{n}+\mathrm{Cat}-H\right]^{+},\left[\bar{z}_{n}+\mathrm{Cat}-H\right]^{+} \cdot$ and $\left[\bar{z}_{n}+\mathrm{Cat}\right]^{+}$species as obtained from the ECD spectra of metalated NGGGWGGGN. The black bar represent the relative intensity of $\left[\bar{c}_{n}+\mathrm{Cat}\right]^{+}$or $\left[\bar{z}_{n}+\mathrm{Cat}-\mathrm{H}\right]^{+} \cdot$ ions and the white bar represent the relative intensity of $\left[\bar{c}_{n}+\mathrm{Cat}-\mathrm{H}\right]^{+} \bullet$ or $\left[\bar{z}_{n}+\mathrm{Cat}\right]^{+}$ions

\begin{tabular}{|c|c|c|c|c|c|}
\hline & \multicolumn{5}{|c|}{ Precursor ions } \\
\hline & $\mathrm{n}^{\mathrm{a}}$ & {$[\mathrm{M}+\mathrm{Mg}]^{2+}$} & {$[\mathrm{M}+\mathrm{Ca}]^{2+}$} & {$[\mathrm{M}+\mathrm{Sr}]^{2+}$} & {$[\mathrm{M}+\mathrm{Ba}]^{2+}$} \\
\hline \multirow{5}{*}{$\overline{c \text { c-Type fragment ions }}{ }^{\mathrm{b}}$} & 8 & D & $\square$ & $\square$ & - \\
\hline & 7 & $\square$ & 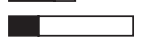 & $\square$ & 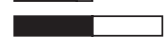 \\
\hline & 6 & $\square$ & C & 口 & \\
\hline & 5 & $\square$ & & $\square$ & $\square$ \\
\hline & 4 & $\square$ & & $\bar{\square}$ & $\square$ \\
\hline \multirow[t]{5}{*}{$z$-Type fragment ions ${ }^{b}$} & 8 & & & $\overline{\mathbf{n}}$ & \\
\hline & 7 & 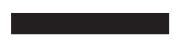 & C & $\square$ & \\
\hline & 6 & $\square$ & $\square$ & $\square$ & $\square$ \\
\hline & 5 & $\square$ & $\square$ & $\square$ & \\
\hline & 4 & & & & \\
\hline
\end{tabular}

${ }^{a} \mathrm{n}$ Represents the number of remaining amino acid residues in the fragments.

bThe relative intensity of $\left[\bar{c}_{n}+\mathrm{Cat}-H\right]^{+\bullet}$ and $\left[\bar{z}_{n}+\mathrm{Cat}-H\right]^{+\bullet}$, ions resulted from the summation of the relative intensities of $\left[\bar{c}_{n} \bar{z}_{n}+\mathrm{Cat}-H\right]^{+\bullet}$ and $\left[\bar{c}_{n} \bar{z}_{n}+\mathrm{Cat}-\mathrm{H}-116\right]^{+}$. 
Table 8. Energies of the model reactions

\begin{tabular}{|c|c|c|c|c|}
\hline \multirow[b]{3}{*}{ Species/reaction } & \multicolumn{4}{|c|}{ Relative energy ${ }^{a}$} \\
\hline & \multirow{2}{*}{$\frac{6-31++G(d, p)}{\text { B3LYP }}$} & \multicolumn{3}{|c|}{$6-311++G(3 d f, 2 p)$} \\
\hline & & B3LYP & PMP2 & B3-MP2 \\
\hline $3 a \rightarrow 3 b$ & 19 & 19 & 21 & 20 \\
\hline $3 b \rightarrow 3 c$ & 8 & 7 & 9 & 8 \\
\hline $3 \mathrm{~b} \rightarrow \mathrm{3e}+\mathrm{CH}_{3} \mathrm{C}(\mathrm{OH})-\mathrm{NH}$ & -26 & -33 & 18 & -8 \\
\hline $3 b \rightarrow 3 d$ & -50 & -49 & -20 & -35 \\
\hline $3 d \rightarrow$ Ts3de & 67 & 65 & 76 & 70 \\
\hline $3 \mathrm{a} \rightarrow 3 \mathrm{~h}+\mathrm{CH}_{3} \mathrm{C}(\mathrm{OH})-\mathrm{NH}$ & 6 & 0 & 53 & 26 \\
\hline $3 a \rightarrow 3 f$ & -44 & -42 & -11 & -26 \\
\hline $3 f \rightarrow T s 3 f g$ & 59 & 58 & 76 & 67 \\
\hline $3 \mathrm{~g} \rightarrow 3 \mathrm{~h}+\mathrm{CH}_{3} \mathrm{C}(\mathrm{OH})-\mathrm{NH}$ & 36 & 32 & 44 & 38 \\
\hline $3 \mathrm{a} \rightarrow 3 \mathrm{j}+\mathrm{CH}_{3} \mathrm{C}(\mathrm{O}) \mathrm{NH}^{\bullet}$ & -48 & -48 & 27 & -10 \\
\hline 3a $\rightarrow$ Ts3ai & 132 & 132 & 153 & 142 \\
\hline $3 \mathrm{i} \rightarrow 3 \mathrm{j}+\mathrm{CH}_{3} \mathrm{C}(\mathrm{O}) \mathrm{NH}^{\bullet}$ & 13 & 7 & 29 & 18 \\
\hline
\end{tabular}

${ }^{\mathrm{a}}$ In units of $\mathrm{KJmol}^{-1}$ at $0 \mathrm{~K}$ including B3LYP/6-31 (d,p) zero-point energy corrections.

tion of the structural modifications from $3 f$ to TS3fg, it was found that the $\mathrm{N}$-terminal $\mathrm{N}-\mathrm{C}_{\alpha}$ linkage elongates from 1.480 to $2.414 \AA$; the N-terminal $\mathrm{N}-\mathrm{H}$ bond lengthens from 1.018 to $1.143 \AA$; and the hydrogen bond distance between the amido hydrogen and the $\mathrm{N}$ terminal amido carbonyl oxygen reduces from 2.185 to $1.387 \AA$. The Eigenvectors for these linkages (or interactions) were found to be $-0.47037,-0.37414$, and 0.68363 , respectively. These numbers were significantly larger than the Eigenvectors for other linkages in TS3fg. This implies that the $\mathrm{N}-\mathrm{C}_{\alpha}$ cleavage and the hydrogen transfer are indeed concerted reaction. This reaction is slightly endothermic and requires moderate activation energy, $\Delta \mathrm{H}_{\mathrm{rxn}}=+15 \mathrm{kJmol}^{-1}$ and $\mathrm{E}_{\mathrm{TS}}=+67 \mathrm{kJmol}^{-1}$ for $3 f \rightarrow$ TS3fg $\rightarrow$ 3g (Scheme 4 ). $3 g$ requires another 38 $\mathrm{kJmol}^{-1}$ energy to produce the final cleavage products, $\mathrm{CH}_{3} \mathrm{C}(\mathrm{OH})=\mathrm{NH}+3 \mathbf{h}$. It is probably worthwhile to note that several attempts have been made to compute this reaction using different starting geometries. For geometries without hydrogen bond between the $\mathrm{N}$ terminal and C-terminal amide groups, such as isomer $3 c$, the transition-state structure for $\mathrm{N}-\mathrm{C}_{\alpha}$ cleavage has no sign for hydrogen atom transfer and yet the reaction product following the intrinsic reaction coordinate (IRC) reaction is also a neutral-radical complex with a hydrogen atom being transferred from the C-terminal fragment to the $\mathrm{N}$-terminal fragment. This implies that the hydrogen atom transfer reaction between the expected products, i.e., $\mathrm{CH}_{3} \mathrm{C}(\mathrm{O}) \mathrm{NH}+\mathrm{CH}_{2}=$ $\mathrm{C}(\mathrm{OH}) \mathrm{NHCH}_{3}$, to form $\mathrm{CH}_{3} \mathrm{C}(\mathrm{OH})=\mathrm{NH}+\mathrm{CH}_{2}=$ $\mathrm{C}(\mathrm{OH}) \mathrm{NCH}_{3}$ is spontaneous with no significant energy barrier. The driving force for such hydrogen atom transfer reaction is tentatively attributed to the higher stabilization of the radical product, i.e., $\mathrm{CH}_{2}=$ $\mathrm{C}(\mathrm{OH}) \mathrm{NCH}_{3}$, through a more extensive conjugated system. Nevertheless, the outcome of this calculation implies that this dissociation pathway is likely to generate products that are isomeric to the conventional $\left[\bar{c}_{n}\right.$ $+2 \mathrm{H}]^{+}$and $\left[\bar{z}_{n}+\mathrm{H}\right]^{+\bullet}$ fragments.

Scheme 5 shows the optimized geometries for the reactant, transition-state, intermediates, and products for dissociation Pathway II. Isomer 3a was again used as the starting geometry. Attachment of a hydrogen atom onto the $\alpha$-carbon leads to the formation of transition-state, TS3ai, in which the $\alpha$-carbon is fivecoordinated with a distorted trigonal bipyramid geometry. Moving from 3a to the transition-state TS3ai, the $\mathrm{N}$-terminal $\mathrm{N}-\mathrm{C}_{\alpha}$ bond lengthened from 1.462 to 1.756 $\AA$. Cleavage of the target $\mathrm{N}-\mathrm{C}_{\alpha}$ linkage leads to the formation of radical-neutral complex, $3 \mathbf{i}$. This reaction is slightly exothermic and requires relatively high activation energy, $\Delta \mathrm{H}_{\mathrm{rxn}}=-29 \mathrm{kJmol}^{-1}$ and $\mathrm{E}_{\mathrm{TS}}=+142$ $\mathrm{kJmol}^{-1}$ for 3a $\rightarrow$ TS3ai $\rightarrow$ 3i (Scheme 5). 3i requires another $18 \mathrm{kJmol}^{-1}$ energy to produce the final cleavage

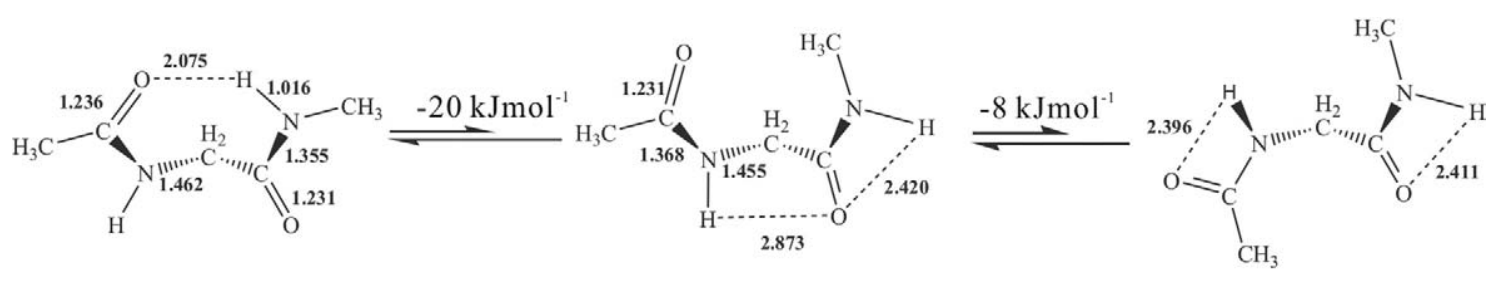




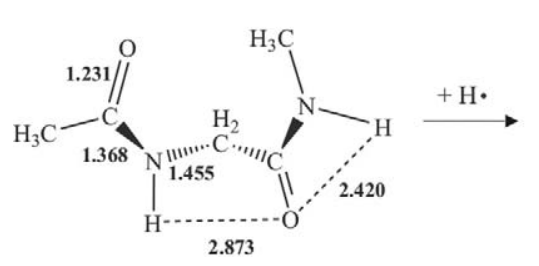

$3 b$

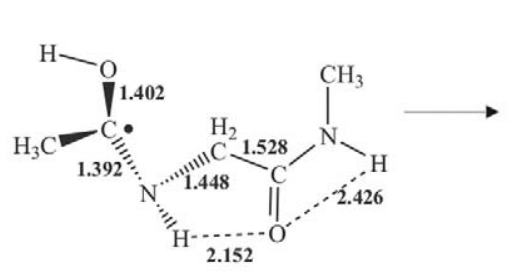

$3 \mathrm{~d}$

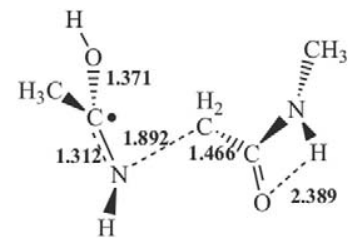

Ts3de

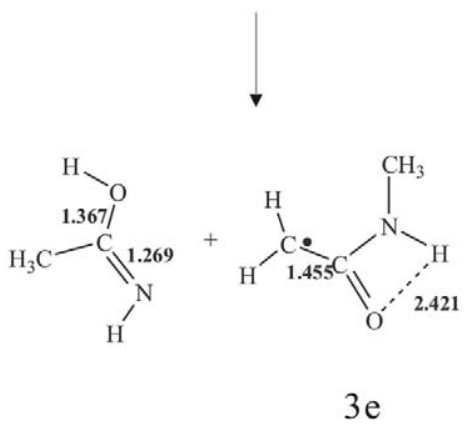

Scheme 3

products, $\mathrm{CH}_{3} \mathrm{C}(\mathrm{OH}) \mathrm{NH}+3 \mathbf{j}$. Although the radical product formed in this reaction is the same as the expected product formed the labile aminoketyl radical (see Scheme 4), no hydrogen atom shift was found between $\mathrm{CH}_{3} \mathrm{C}(\mathrm{OH}) \mathrm{NH}^{\prime}$ and $\mathbf{3 j}$.

Intuitively, there exists another possible reaction pathway, i.e., Pathway III, for the formation of $\left[\bar{c}_{n}+\right.$ $H]^{+}$and $\left[\bar{z}_{n}+2 \mathrm{H}\right]^{+}$fragments. As was demonstrated from a number of studies, the radical $\left[\bar{z}_{n}+H\right]^{+} \cdot$ species initially formed from major $\mathrm{N}-\mathrm{C}_{\alpha}$ cleavage are fairly reactive and are capable of abstracting a hydrogen atom from the $\alpha$-carbon [16] and/or initiating a cascade of degradation reactions under suitable experimental conditions [36]. Suppose there is a time-lag between the $\mathrm{N}-\mathrm{C}_{\alpha}$ cleavage and the separation of the resulting $\left[\bar{c}_{n}+H\right]^{0}$ and $\left[\bar{z}_{n}+H\right]^{+}{ }^{\bullet}\left(\right.$ or $\left[\bar{c}_{n}\right.$ $+2 H]^{+}$and $\left[\bar{z}_{n}{ }^{\bullet}\right)$ fragments, the $\left[\bar{z}_{n}+H\right]^{+}\left(\right.$or $\left.\left[\bar{z}_{n}\right]^{0 \cdot}\right)$ species might abstract a hydrogen atom from the nearby $\alpha$-carbon of the $\left[\bar{c}_{n}+H\right]^{0}\left(\right.$ or $\left.\left[\bar{c}_{n}+2 H\right]^{+}\right)$ species. This reaction will generate the observed $\left[\bar{c}_{n}+\right.$ $H]^{+}$and $\left[\bar{z}_{n}+2 \mathrm{H}\right]^{+}$species. The idea of having a time-lag in the separation can be substantiated by the presence of noncovalent interactions, such as hydrogen bonding interactions, between the separating fragments. Due presumably to the captodative stabilization of the resulting carbon radical, this reaction is found to be slightly exothermic and requires only moderate activation energy, $\Delta \mathrm{H}_{\mathrm{rxn}}=-41 \mathrm{kJmol}^{-1}$

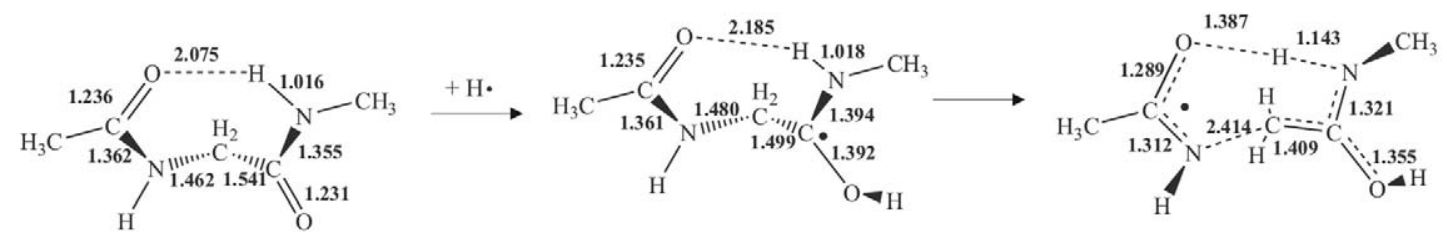

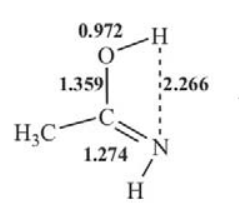

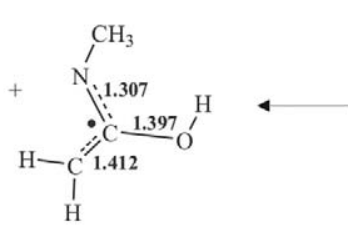

$3 \mathrm{~h}$

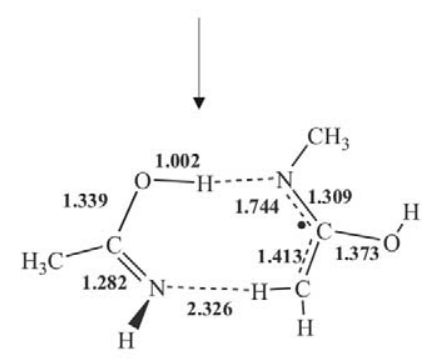

$3 \mathrm{~g}$

Scheme 4 


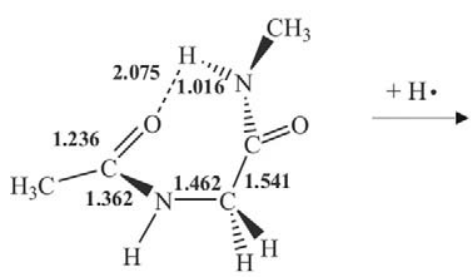

$3 a$

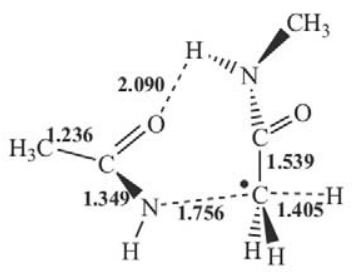

Ts3ai

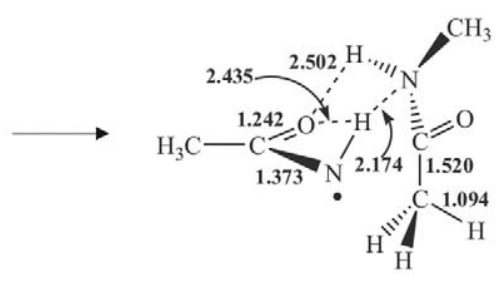

$3 \mathrm{i}$

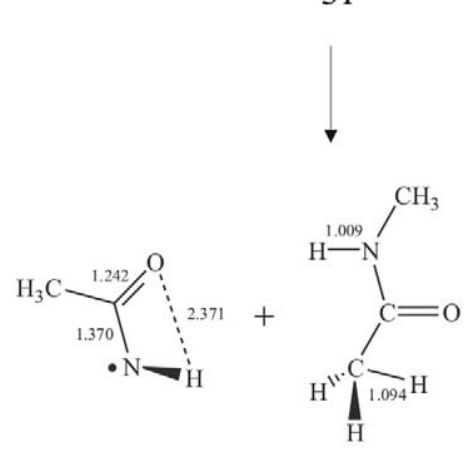

$3 \mathrm{j}$

Scheme 5

and $\mathrm{E}_{\mathrm{TS}}=+76 \mathrm{kJmol}^{-1}$ (see reaction $2 \mathrm{~b} \rightarrow$ TS2be $\rightarrow$ $2 \mathrm{e}$ in reference [15]).

From the energetics point-of-view, Pathways I and III should compete favorably with the major dissociation pathway; and Pathway II requires substantially higher activation energy and is, therefore, less likely to be an important reaction pathway. In Pathway I, the formation of $\left[\bar{c}_{n}+H\right]^{+}$and $\left[\bar{z}_{n}+2 H\right]^{+}$through the cleavage of the $\mathrm{N}$-terminal $\mathrm{N}-\mathrm{C}_{\alpha}$ linkage is prohibited by the concerted (or stepwise) hydrogen shift. In pathway III, the formation of $\left[\bar{c}_{n}+H\right]^{+}$and $\left[\bar{z}_{n}+2 H\right]^{+}$is facilitated by the hydrogen shift between the initially formed $\left[\bar{c}_{n}+2 H\right]^{+}$and $\left[\bar{z}_{n}+H\right]^{+}$species. Since the hydrogen shift reactions associated with Pathways I and III have opposite effect on the production of minor ECD products, it might be possible to determine the relative contribution of these pathways under typical ECD conditions. Empirically, Zubarev and coworkers found that the formation of minor ECD products is dependent of the mass and the charge-state of the precursor ion [46]. For a 21-mer peptide, the $4+$ precursor ion produces no observable $\left[\bar{c}_{n}+H\right]^{+}$and $\left[\bar{z}_{n}+\right.$ $2 \mathrm{H}]^{+}$fragments; whereas $3+$ precursor ion generates abundant minor ECD products. Ubiquitin and larger proteins show no observable $\left[\bar{c}_{n}+H\right]^{+}$and $\left[\bar{z}_{n}+2 \mathrm{H}\right]^{+}$ fragments. Since the charge state of any precursor ions scales up with the mass of the proteins under typical electrospray ionization conditions, the mass dependent effect can also be considered as the charge state dependent effect. In short, precursor ions with high charge state (possibly $>3$ ) would show negligible minor ECD products. Obviously, the higher is the initial charge state of the precursor ions, the larger would be the Coulombic repulsion between the fragments after $\mathrm{N}-\mathrm{C}_{\alpha}$ cleavage, and the faster would be the separation of the fragments. Based on this postulation, Pathway III is more likely to be the main pathway for the formation of $\left[\bar{c}_{n}+H\right]^{+}$and $\left[\bar{z}_{n}+2 \mathrm{H}\right]^{+}$fragments.

In a metalated peptide, metal ion is commonly solvated by multiple amido carbonyl oxygen atoms [40] and, thus, provides a tighter noncovalent network within the peptide ion. This noncovalent network would substantially increase the lag time between the $\mathrm{N}-\mathrm{C}_{\alpha}$ bond cleavage and the subsequent separation of the ECD fragments. This would facilitate efficient hydrogen transfer from the $\alpha$-carbons of the $c$-type fragment to the terminal $\alpha$-carbon radical of the $z$-type fragment and, thus, provide intense $\left[\bar{c}_{n}+H\right]^{+}$and $\left[\bar{z}_{n}\right.$ $+2 \mathrm{H}]^{+}$fragments. It is, however, important to note that metal ion coordination at the amido carbonyl oxygen atoms might also stabilize the amido nitrogen radical formed in Pathway I and, thus, prevent the subsequent hydrogen atom transfer. Therefore, the possible contribution of Pathway I for the observed $\left[\bar{c}_{n}+H\right]^{+}$and $\left[\bar{z}_{n}\right.$ $+2 \mathrm{H}]^{+}$fragments cannot be excluded.

\section{Use of Alkaline Earth Metal Ions as Charge-Carrier for ECD of Peptides}

Perhaps it is worthy to point out that multiple attempts using different experimental conditions did not lead to the formation of appreciable doubly-protonated NGGGWGGGN molecular ions. Increasing acetic acid percentage of the sample solution up to $10 \%$ or replacing acetic acid with formic acid did not improve the situation. Conventional electron capture dissociation experiment could, therefore, not be performed. However, intense 
doubly-charged molecular ions could be generated by simply doping a small amount of alkaline-earth metal salt into the analyte solution. As demonstrated, useful ECD tandem mass spectrum could be generated.

Apart from the model peptides, several metalated bioactive peptides have also been studied under electron capture dissociation conditions. Take Substance P as an example; series of $\left[\bar{c}_{n}+\mathrm{Cat}-\mathrm{H}^{+}\right]^{\bullet},\left[\bar{c}_{n}+\mathrm{Cat}\right]^{+}$, $\left[\bar{z}_{n}+\mathrm{Cat}-\mathrm{H}\right]^{+\bullet}$, and $\left[\bar{z}_{n}+\mathrm{Cat}\right]^{+}$were observed. Similar to the observations obtained using model peptides, $\left[\bar{c}_{n}+\mathrm{Cat}-\mathrm{H}\right]^{+} \cdot$ and $\left[\bar{z}_{n}+\right.$ Cat $]$ were generally found to have higher abundance than the corresponding $\left[\bar{c}_{n}+\mathrm{Cat}\right]^{+}$and $\left[\bar{z}_{n}+\mathrm{Cat}-\mathrm{H}\right]^{+} \cdot$ fragments. In addition, two $z$-ions (i.e., $\left[\bar{z}_{7}+\mathrm{Cat}\right]^{+}$and $\left[\bar{z}_{9}+\mathrm{Cat}\right]^{+\bullet}$ ) were observed in the ECD of metalated Substance P, whereas only one $z$-ion (i.e., $\left[\bar{z}_{9}+H\right]^{+\bullet}$ ) was observed in the case of doubly-protonated Substance P. Our results demonstrated that the use of divalent metal ions as charge carries for ECD of peptides provides complementary information to the ECD of protonated peptides.

\section{Conclusions}

Attachment of alkaline-earth metal ions onto a peptide could activate the acidity of amide hydrogen. The [M + Cat $]^{2+}$ should exist in several isomeric forms, including $[\mathrm{M}+\mathrm{Cat}]^{2+},[(\mathrm{M}+\mathrm{Cat}-\mathrm{H})+\mathrm{H}]^{2+}$, and $[(\mathrm{M}+\mathrm{Cat}-$ $2 \mathrm{H})+2 \mathrm{H}]^{2+}$. It was believed that the relative contribution of these species depends on the identity of the alkaline-earth metal ion (Cat) and the availability of the basic functionalities within the peptide molecule (M). Electron capture dissociation of metalated peptides proceeds primarily through the usual electron-proton recombination channel. This accounts for the formation of apparently similar fragment spectra for peptides metalated with different alkaline-earth metal ions. Various possible formation channels for minor dissociation products in ECD of protonated peptides were evaluated theoretically using ab initio calculations. These results were extended to account for the formation of unexpectedly high intensity $[c+\mathrm{Cat}-\mathrm{H}]^{+}$and $[z+\mathrm{Cat}]^{+}$ fragments in ECD of metalated peptides.

\section{Acknowledgments}

The work described in this paper was fully supported by a grant from the Research Grants Council of the Hong Kong Special Administrative Region, China (project no. 400603). The calculations were carried out in part using the IBM RS/6000 SP system in the Information Technology Services Center (ITSC) at the Chinese University of Hong Kong. The authors thank the ITSC for generous allocation of computing time of the system.

\section{References}

1. Sze, S. K.; Ge, Y.; Oh, H.; McLafferty, F. W. Top-Down Mass Spectrometry of a 29-kDa Protein for Characterization of Any Post-translational Modification to Within One Residue. Proc. Natl. Acad. Sci. U.S.A. 2002, 99, 1774-1779.
2. Zubarev, R. A.; Kelleher, N. L.; McLafferty, F. W. Electron Capture Dissociation of Multiply Charged Protein Cations. A Nonergodic Process. J. Am. Chem. Soc. 1998, 120, 3265-3266.

3. Hayes, R. N.; Gross, M. L. Collision-Induced Dissociation. Methods Enzymol. 1990, 193, 237-263; (b) Little, D. P.; Speir, J. P.; Senko, M. W.; O'Connor, P. B.; McLafferty, F. W. Infrared Multiphoton Dissociation of Large Multiply-Charged Ions for Biomolecule Sequencing. Anal. Chem. 1994, 66, 2809-2815; (c) Price, W. D.; Schnier, P. D.; Williams, E. R. Tandem Mass Spectrometry of Large Biomolecule Ions by Blackbody Infrared Radiative Dissociation. Anal. Chem. 1996, 68, 859-866.

4. Mirgorodskaya, E.; Roepstorff, P.; Zubarev, R. A. Localization of O-Glycosylation Sites in Peptides by Electron Capture Dissociation in a Fourier Transform Mass Spectrometer. Anal. Chem. 1999, 71, 4431-4436.

5. Shi, S. D. H.; Hemling, M. E.; Carr, S. A.; Horn, D. M.; Lindh, I.; McLafferty, F. W. Phosphopeptide/Phosphoprotein Mapping by Electron Capture Dissociation Mass Spectrometry. Anal. Chem. 2001, 73, 19-22.

6. Kelleher, R. L.; Zubarev, R. A.; Bush, K.; Furie, B.; Furie, B. C.; McLafferty, F. W. Walsh, C. T. Localization of Labile Post-translational Modifications by Electron Capture Dissociation: The case of $\gamma$-Carboxyglutamic Acid. Anal. Chem. 1999, 71, 4250-4253.

7. Guan, Z. Q. Identification and Localization of the Fatty Acid Modification in Ghrelin by Electron Capture Dissociation. J. Am. Soc. Mass Spectrom. 2002, 13, 1443-1447.

8. Guan, Z. Q.; Yates, N. A.; Bakhtiar, R. Detection and Characterization of Methionine Oxidation in Peptides by Collision-Induced Dissociation and Electron Capture Dissociation. J. Am. Soc. Mass Spectrom. 2003, 14, 605-613.

9. Kjeldsen, F.; Haselmann, K. F.; Budnik, B. A.; Sorensen, E. S.; Zubarev, R. A. Complete Characterization of Post-translational Modification Sites in the Bovine Milk Protein PP3 by Tandem Mass Spectrometry with Electron Capture Dissociation as the Last Stage. Anal. Chem. 2003, 75, 2355-2361.

10. Chan, T. W. D.; Ip, W. H. H. Optimization of Experimental Parameters for Electron Capture Dissociation of Peptides in a Fourier Transform Mass Spectrometer. J. Am. Soc. Mass Spectrom. 2002, 13, 1396-1406.

11. Tsybin, Y. O.; Witt, M.; Baykut, G.; Hakansson, P. Electron Capture Dissociation Fourier Transform Ion Cyclotron Resonance Mass Spectrometry in the Electron Energy range 0-50 eV. Rapid Commun. Mass Spectrom. 2004, 18, 1607-1613.

12. Zubarev, R. A. Reactions of Polypeptide Ions with Electrons in the Gas Phase. Mass Spectrom. Rev. 2003, 22, 57-77.

13. Kjeldsen, F.; Haselmann, K. F.; Budnik, B. A.; Jensen, F.; Zubarev, R. A. Dissociative Capture of Hot (3-13 eV) Electrons by Polypeptide Polycations: An Efficient Process Accompanied by Secondary Fragmentation. Chem. Phys. Lett. 2002, 356, 201-206.

14. Cooper, H. J.; Hudgins, R. R.; Hakansson, K.; Marshall, A. G. Characterization of Amino Acid Side Chain Losses in Electron Capture Dissociation. J. Am. Soc. Mass Spectrom. 2002, 13, 241-249.

15. Kjeldsen, F.; Zubarev, R. Secondary Losses via $\gamma$-Lactam Formation in Hot Electron Capture Dissociation: A Missing Link to Complete de Novo Sequencing of Proteins? J. Am. Chem. Soc. 2003, 125, 6628-6629.

16. Fung, Y. M. E.; Chan, T. W. D. Experimental and Theoretical Investigations of the Loss of Amino Acid Side Chains in Electron Capture Dissociation of Model Peptides. J. Am. Soc. Mass Spectrom. 2005, 16, 1523-1535.

17. Gorshkov, M. V.; Masselon, C. D.; Nikolaev, E. N.; Udseth, H. R.; Pasa-Tolic, L.; Smith, R. D. Considerations for Electron Capture Dissociation Efficiency in FTICR Mass Spectrometry. Int. J. Mass Spectrom. 2004, 234, 131-136.

18. Tsybin, Y. O.; Hakansson, P.; Budnik, B. A.; Haselmann, K. F.; Kjeldsen, F.; Gorshkov, M.; Zubarev, R. A. Improved Low-Energy Electron Injection Systems for High Rate Electron Capture Dissociation in Fourier Transform Ion Cyclotron Resonance Mass Spectrometry. Rapid Commun. Mass Spectrom. 2001, 15, 1849-1854.

19. Niiranen, H.; Budnik, B. A.; Zubarev, R. A.; Auriola, S.; Lapinjoki, S. High-Performance Liquid Chromatography-Mass Spectrometry and Electron-Capture Dissociation Tandem Mass Spectrometry of Osteocalcin-Determination of $\gamma$-Carboxyglutamic Acid Residues. J. Chromatogr. A 2002, 962, 95-103.

20. Palmblad, M.; Tsybin, Y. O.; Ramstrom, M.; Bergquist, J.; Hakansson, P. Liquid Chromatography and Electron-Capture Dissociation in Fourier Transform Ion Cyclotron Resonance Mass Spectrometry. Rapid Commun. Mass Spectrom. 2002, 16, 988-992.

21. Davidson, W.; Frego, L. Micro-High-Performance Liquid Chromatography/Fourier Transform Mass Spectrometry with Electron-Capture Dissociation for the Analysis of Protein Enzymatic Digests. Rapid Commun. Mass Spectrom. 2002, 16, 993-998.

22. Mihalca, R.; Kleinnijenhuis, A. J.; McDonnell, L. A.; Heck, A. J. R.; Heeren, R. M. A. Electron Capture Dissociation at Low Temperatures Reveals Selective Dissociations. I. Am. Soc. Mass Spectrom. 2004, 15, 1869-1873.

23. Iavarone, A. T.; Paech, K.; Williams, E. R. Effects of Charge State and Cationizing Agent on the Electron Capture Dissociation of a Peptide. Anal. Chem. 2004, 76, 2231-2238.

24. Horn, D. M.; Ge, Y.; McLafferty, F. W. Activated Ion Electron Capture Dissociation for Mass Spectral Sequencing of Larger (42 kDa) Proteins. Anal. Chem. 2000, 72, 4778-4784. 
25. Sze, S. K.; Ge, Y.; Oh, H. B.; McLafferty, F. W. Plasma Electron Capture Characterization of Large Dissociation for the Proteins by Top Down Mass Spectrometry. Anal. Chem. 2003, 75, 1599-1603.

26. Zubarev, R. A. Haselmann, K. F.; Budnik, B.; Kjeldsen, F.; Jensen, F.Towards an Understanding of the Mechanism of Electron-Capture Dissociation: A Historical Perspective and Modern Ideas.Eur. J. Mass Spectrom.83372002349

27. Hakansson, K.; Hudgins, R. R.; Marshall, A. G. Electron Capture Dissociation and Infrared Multiphoton Dissociation of Oligodeoxynucleotide Dications. J. Am. Soc. Mass Spectrom. 2003, 14, 23-41.

28. John, E. The Elements, 2nd ed.; Clarendon Press: Oxford, 1998, pp 26, 27, $42,43,88,89,110,111,180,181$.

29. Lau, R. L. C.; Jiang, J. Z.; Ng, D. K. P.; Chan, T. W. D. Fourier Transform Ion Cyclotron Resonance Studies of Lanthanide(III) Porphyrin-Phthalocyanine Heteroleptic Sandwich Complexes by Using Electrospray Ionization. J. Am. Soc. Mass Spectrom. 1997, 8, 161-169.

30. Fong, K. W. Y.; Chan, T. W. D. A Novel Nonmetallized Tip for Electrospray Mass Spectrometry at Nanoliter Flow Rate. I. Am. Soc. Mass Spectrom. 1999, 10, 72-75.

31. Caravatti, P.; Allemann, M. The Infinity Cell-A New Trapped-Ion Cell with Radiofrequency Covered Trapping Electrodes for Fourier-Transform Ion-Cyclotron Resonance Mass-Spectrometry. Org. Mass Spectrom. 1991, 26, 514-518

32. Frisch, M. J.; Trucks, G. W.; Schlegel, H. B.; Scuseria, G. E.; Robb, M. A.; Cheeseman, J. R.; Montgomery, J. A., Jr.; Vreven, T.; Kudin, K. N.; Burant, J. C.; Millam, J. M.; Iyengar, S. S.; Tomasi, J.; Barone, V.; Mennucci, B.; Cossi, M.; Scalmani, G.; Rega, N.; Petersson, G. A.; Nakatsuji, H.; Hada, M.; Ehara, M.; Toyota, K.; Fukuda, R.; Hasegawa, J.; Ishida, M.; Nakajima, T.; Honda, Y.; Kitao, O.; Nakai, H.; Klene, M.; Li, X.; Knox, J. E.; Hratchian, H. P.; Cross, J. B.; Adamo, C.; Jaramillo, J.; Gomperts, R.; Stratmann, R. E.; Yazyev, O.; Austin, A. J.; Cammi, R.; Pomelli, C.; Ochterski, J. W.; Ayala, P. Y.; Morokuma, K.; Voth, G. A.; Salvador, P.; Dannenberg, J. J.; Zakrzewski, V. G.; Dapprich, S.; Daniels, A. D.; Strain, M. C.; Farkas, O.; Malick, D. K.; Rabuck, A. D.; Raghavachari, K.; Foresman, J. B.; Ortiz, J. V.; Cui, Q.; Baboul, A. G.; Clifford, S.; Cioslowski, J.; Stefanov, B. B.; Liu, G.; Liashenko, A.; Piskorz, P.; Komaromi, I.; Martin, R. L.; Fox, D. J.; Keith, T.; Al-Laham, M. A.; Peng, C. Y.; Nanayakkara, A.; Challacombe, M.; Gill, P. M. W.; Johnson, B.; Chen, W.; Wong, M. W.; Gonzalez, C.; Pople, J. A. Gaussian 03, Revision B. 04 ed.; Gaussian, Inc.: Pittsburgh PA.

33. Becke, A. D. A New Mixing of Hartress-Fock and Local DensityFunctional Theories. J. Chem. Phys. 1993, 98, 1372-1377; (b) Becke, A. D. Density Functional Thermochemistry, III. The Role of Exact Exchange. J. Chem. Phys. 1993, 98, 5648-5652; (c) Stephens, P. J.; Delvin, F. J.; Cabalowski, C. F.; Fisch, M. J. Ab Initio Calculation of Vibrational Absorption and Circular Dichroism Spectra Using Density Functional Force Fields. J. Phys. Chem. 1994, 98, 11623-11627.

34. Scott, A. P.; Radom, L. Harmonic Vibrational Frequencies: An Evaluation of Hartree-Fock, Moller-Plesset Quadratic Configuration Interaction, Density Functional Theory, and Semiempirical Scale Factors. J. Phys. Chem. 1996, 100, 16502-16513.

35. Turecek, F. Proton Affinity of Dimethyl Sulfoxide and Relative Stabilities of $\mathrm{C}_{2} \mathrm{H}_{6} \mathrm{OS}$ Molecules and $\mathrm{C}_{2} \mathrm{H}_{7} \mathrm{OS}^{+}$Ions. A Comparative G2(MP2) ab Initio and Density Functional Theory Study. J. Phys. Chem. A 1998, 102, 4703-4713; (b) Wolken, J. K.; Turecek, F. Heterocyclic Radicals in the Gas Phase. An Experimental and Computational Study of 3-Hydroxypyridinium Radicals and Cations. J. Am. Chem. Soc. 1999, 121, 6010-6018; (c) Polasek, M.; Turecek, F. Hydrogen Atom Adducts to Nitrobenzene: Formation of the Phenylnitronic Radical in the Gas Phase and Energetics of Wheland Intermediates. J. Am. Chem. Soc. 2000, 122, 9511-9524.

36. Leymarie, N.; Costello, C. E.; O'Connor, P. B. Electron Capture Dissociation Initiates a Free Radical Reaction Cascade. J. Am. Chem. Soc. 2003, $125,8949-8958$.

37. Wong, C. K. L.; Chan, T. W. D. Cationization Processes in MatrixAssisted Laser Desorption/Ionization Mass Spectrometry: Attachment of Divalent and Trivalent Metal Ions. Rapid Commun. Mass Spectrom. 1997, 11, 513-519.

38. Rulisek, L.; Vondrasek, J. Coordination Geometries of Selected Transition Metal Ions $(\mathrm{Co} 2+, \mathrm{Ni} 2+, \mathrm{Cu} 2+, \mathrm{Zn} 2+, \mathrm{Cd} 2+$, and $\mathrm{Hg} 2+)$ in Metalloproteins. J. Inorg. Biochem. 1998, 71, 115-127.

39. Sigel, H.; Martin, R. B. Coordinating Properties of the Amide BondStability and Structure of Metal-Ion Complexes of Peptides and Related Ligands. Chem. Rev. 1982, 82, 385-426.

40. Kohtani, M.; Jarrold, M. F.; Wee, S.; O'Hair, R. A. J. Metal-Ion Interactions with Polyalanine Peptides. J. Phys. Chem. B 2004, 108, 6093-6097.

41. Tomlinson, M. J.; Scott, J. R.; Wilkins, C. L.; Wright, J. B.; White, W. E. Fragmentation of an Alkali Metal-Attached Peptide Probed by Collision-Induced Dissociation Fourier Transform Mass Spectrometry and Computational Methodology. J. Mass Spectrom. 1999, 34, 958-968.

42. Miaskiewicz, K.; Sadlej, J. The Investigation of Ion Formamide Interactions by ab Initio Model Calculations. Theochem. J. Mol. Struct. 1985, 25, 223-230; (b) Fussenegger, R.; Rode, B. M. Effect of Metal-Ion Bonding to Amides on Character of C-N Bond of Ligand Molecule. Chem. Phys. Lett. 1976, 44, 95-99.

43. Syrstad, E. A.; Stephens, D. D.; Turecek, F. Hydrogen Atom Adducts to the Amide Bond. Generation and Energetics of Amine Radicals in the Gas Phase. J. Phys. Chem. A 2003, 107, 115-126; (b) Turecek, F.; Syrstad, E. A. Mechanism and Energetics of Intramolecular Hydrogen Transfer in Amide and Peptide Radicals and Cation Radicals. J. Am. Chem. Soc. 2003, 125, 3353-3369; (c) Turecek, F.; Syrstad, E. A.; Seymour, J. L.; Chen, X.; Yao, C. Peptide Cation-Radicals. A Computational Study of the Competition Between Peptide $\mathrm{N}-\mathrm{C}_{\alpha}$ Bond Cleavage and Loss of the Side Chain in [GlyPhe- $\left.\mathrm{NH}_{2}+2 \mathrm{H}\right]^{+} \bullet$ Cation-Radical. J. Mass Spectrom. 2003, 38, 1093-1104.

44. Syrstad, E. A.; Turecek, F. Toward a General Mechanism of Electron Capture Dissociation. J. Am. Soc. Mass Spectrom. 2005, 16, 208-224.

45. Turecek, F. N-C- $\alpha$ Bond Dissociation Energies and Kinetics in Amide and Peptide Radicals. Is the Dissociation a Nonergodic Process? J. Am. Chem. Soc. 2003, 125, 5954-5963.

46. Zubarev, R. A.; Horn, D. M.; Fridriksson, E. K.; Kelleher, N. L.; Kruger, N. A.; Lewis, M. A.; Carpenter, B. K.; McLafferty, F. W. Electron Capture Dissociation for Structural Characterization of Multiply Charged Protein Cations. Anal. Chem. 2000, 72, 563-573. 